\author{
Gaspar Fernández Cuesta \\ Departamento de Geografía. Universidad de Oviedo
}

\title{
Valladolid: la construcción de la ciudad burguesa sin ensanches
}

\section{RESUMEN}

En este artículo, sobre las peculiaridades urbanísticas de las ciudades que levantaron su espacio burgués sobre la trama heredada del Antiguo Régimen, sin utilizar la figura del ensanche, hemos elegido Valladolid por considerar que es, tal vez, el mejor ejemplo español de lo que sido el desarrollo urbano de este tipo de ciudades entre 1850 y 1930.

\section{RÉsumÉ}

Valladolid: la construction de la ville bourgeoise sans évasements.Dans cet article sur les particularités urbanistiques des villes, dans lesquelles l'espace bourgeois s'élève sur le tracé hérité de l'Ancien Régime au lieu de suivre le schéma de l'ensanche, nous avons choisi Valladolid en considérant qu'elle est peut être le meilleur exemple espagnol du développement urbain de ce type de villes entre 1850 et 1930 .

\section{INTRODUCCIÓN}

$E$ modelo de ciudad construido en España durante el Antiguo Régimen comenzó a cambiar de forma muy rápida con la llegada de la industrialización; tanto que pronto surgió una ciudad de características bien distintas a la que, por el protagonismo que adquirió en su formación la clase dirigente que lideró los cambios, se le ha dado el calificativo de «burguesa». La formación de esta ciudad se alargó desde mediados del siglo XIx, cuando irrumpen las primeras instalaciones fabriles, hasta mediados del siglo xx; en concreto, hasta 1956, el año en el que se aprobó la primera ley del Suelo. Ahora bien, la fase álgida de la ciudad burguesa no llegó más allá de la década de 1930, pues a partir de entonces el urbanismo español decimonónico comenzó a incorporar cada vez con más fuerza los principios racionalistas,
ABSTRACT

Valladolid: the construction of the bourgeois city without extensions.In this article about the urban peculiarities of the cities, in which the bourgeois urban space emerged upon the inherited medieval layout instead of following the principles of the ensanche, we chose Valladolid considering it may be the best Spanish example of the urban development of this type of cities between 1850 and 1930 .

\section{Palabras Clave/Mots clé/Keywords}

Valladolid, espacio burgués, crecimiento urbano. Valladolid, l'espace bourgeois, le développement urbain. Valladolid, the bourgeois urban, the urban development.

difundidos en esta época por la Carta de Atenas ${ }^{1}$, que poco a poco suplantaron a los que habían servido para construir aquélla.

Dentro de la nueva ciudad, la clase dirigente levantó un espacio destinado a satisfacer sus propias necesidades, tanto residenciales como de ocio y equipamientos, y para ello se sirvió de dos instrumentos urbanísticos: la reforma interior ${ }^{2}$, que tenía como objetivo adecuar la

\footnotetext{
${ }^{1}$ La Carta de Atenas buscaba un urbanismo más justo que el decimonónico. Planteaba el uso del polígono como unidad de planificación, la separación espacial de los usos del suelo, la proliferación de espacios verdes, la ruptura con el plano ortogonal, o la construcción en abierto dentro de las manzanas.

${ }^{2}$ Las actuaciones urbanísticas dirigidas a adaptar la trama de la ciudad histórica a las necesidades de la sociedad industrial recibieron el nombre de reforma interior. Ésta incluyó obras de saneamiento, abastecimiento y embellecimiento; la construcción de grandes equipamientos y espacios de ocio y esparcimiento; o el ensanchamiento y apertura de calles. Una de las principales leyes que amparó
} 
trama urbana heredada a las nuevas necesidades de la sociedad, y los ensanches, o planes de expansión para producir suelo urbano, que fueron diseñados al amparo de las principales leyes urbanísticas aprobadas por los gobiernos centrales durante la segunda mitad del siglo XIX ${ }^{3}$.

Las actuaciones de reforma interior, aun cuando nos han dejado legados tan importantes como las grandes vías, son difíciles de identificar cuando analizamos los planos actuales de las ciudades, pues han quedado circunscritas a los cascos históricos y éstos ocupan, generalmente, una parte muy reducida de la trama urbana. Los barrios surgidos de los proyectos de ensanche son, por el contrario, mucho más reconocibles, tanto en el plano como en el paisaje. $\mathrm{Su}$ tamaño suele ser mucho mayor y poseen un carácter emblemático, tanto por su trama marcadamente ortogonal como por su posición central, por la sensación de orden que dimana de ellos, el valor de su diseño, la calidad de los edificios que se alinean siguiendo el perímetro exterior de las manzanas o por las perspectivas que diseñan sus amplias avenidas. Así ocurre todavía en la mayoría de las principales ciudades, como Barcelona, Madrid, San Sebastián, Bilbao, Valencia, León, Palma de Mallorca, Alicante, Albacete, Cartagena, Vigo, Sabadell, Gijón, Alcoy, etcétera.

Ahora bien, en unas pocas de las grandes ciudades, entre las que podemos citar Granada, Sevilla, Málaga o Valladolid $^{4}$, la construcción del espacio burgués siguió pautas bien distintas, pues éste se diseñó casi de forma exclusiva a partir de obras de reforma interior, es decir, sobre la trama de la ciudad histórica y no sobre ensanches proyectados sobre suelo rústico. Por tanto, en estas ciudades la huella de estos últimos es prácticamente inexistente, bien porque nunca dispusieron de este instrumento urbanístico, bien porque, aun cuando lo tuvieron, o no

la reforma interior fue la Real orden sobre expedientes de alineación de calles y plazas, aprobada en 1854 (Carazo Lefort, 2010, p. 41).

${ }^{3}$ El nombre de ensanche procede del que tuvieron las leyes urbanísticas que los promovieron. La primera Ley de Ensanche fue aprobada en 1864. Recogía ideas de Ildefonso Cerdá en el campo de la gestión, como los deberes de los propietarios del suelo y de la administración; las fórmulas que deberían ser utilizadas para la cesión de viales; los mecanismos de reparcelación; o las cargas y beneficios que deberían de ser aplicados a los propietarios para compensar las alteraciones del precio del suelo provocadas por el proyecto (Terán, 1999, pp. 56-63). Otras dos leyes de ensanche se aprobaron en 1876 y 1892, y a ellas habría que añadir el Estatuto Municipal de 1924, pues mantuvo en vigor los principios teóricos y de gestión de aquéllos (Delgado Viñas, 1993, pp. 131-133). La principal aportación de este último consistió en transferir la competencia urbanística, hasta entonces gubernamental, a los ayuntamientos, y en obligar a todos los municipios de más de veinte mil habitantes a dotarse de su propio proyecto de ensanche (Bassols Coma, 1973).

${ }^{4}$ Estas ciudades alcanzaron su esplendor durante el siglo xvı y después pasaron por un largo letargo que se prolongó hasta las primeras décadas del siglo XIX. En ese momento el tamaño de su casco histórico era desproporcionado para la población que tenían entonces. llegaron a ejecutarlo o lo hicieron en una mínima proporción respecto a lo que se había proyectado.

La razón de este comportamiento no es, en absoluto, caprichosa. Hay que buscarla en el tamaño que tenían a mediados del siglo XIX sus cascos históricos, sin duda sobredimensionados para la población que tenían entonces. Pero también en la proliferación de edificios religiosos que, al ser desamortizados (y muchos de ellos derruidos), dieron lugar a grandes baldíos factibles de ser destinados a otros usos. Cuando la llegada de las primeras fábricas aceleró el ritmo de crecimiento de la población y las necesidades de espacio, la burguesía pudo prescindir de la figura del ensanche, pues disponía del suelo suficiente para hacerlo en el interior del recinto histórico.

En este artículo sobre las peculiaridades urbanísticas de las ciudades que levantaron su espacio burgués sobre la trama heredada del Antiguo Régimen, hemos elegido Valladolid por considerar que es, tal vez, el mejor ejemplo español de lo que fue el desarrollo urbano de este tipo de ciudades entre 1850 y 1930. Un artículo que pretende ser una síntesis bibliográfica, cuya mayor originalidad y principal aportación reside en la utilización exhaustiva del lenguaje cartográfico, uno de los que con mayor eficacia y sencillez transmite el conocimiento geográfico. Además, el artículo complementa a otro anterior sobre San Sebastián (Fernández Cuesta, 2012), con el que se pretendió modelizar la construcción del espacio burgués mediante la figura del ensanche.

\section{LA CIUDAD PREINDUSTRIAL}

\section{LOS ORÍGENES}

En su origen, el emplazamiento de Valladolid, sobre la terraza superior de la margen izquierda del río Pisuerga, en el lugar en el que éste recibía las aguas del Esgueva a través de dos brazos, era envidiable. Y lo mismo ocurría con su situación, en el centro geográfico de la cuenca hidrográfica del Duero cerca de su confluencia con el Pisuerga, por donde discurrían algunas de las principales vías de comunicación castellanas (García Fernández, 2000, pp. 15-29).

Los primeros vestigios de la ciudad se remontan a la época del Imperio romano. Fue entonces cuando sobre la lengua de tierra formada por los dos brazos del Esgueva surgió un primer asentamiento agrícola, que tuvo continuidad durante el periodo visigodo, pero se abandonó después de la invasión árabe y permaneció deshabitado durante cerca de doscientos años (Marchán Fiz y Moya González, 1982, pp. 7-10). 


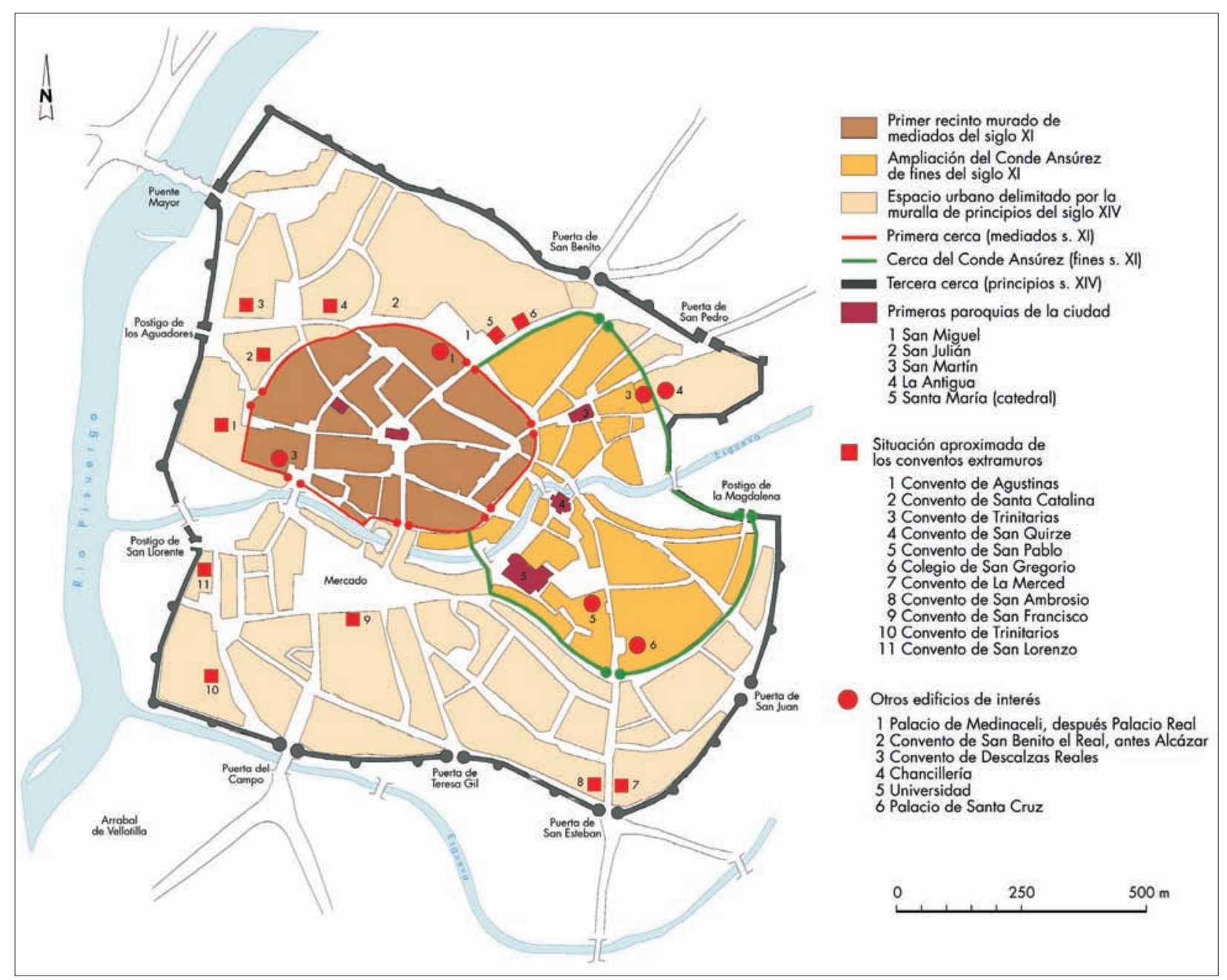

FIG. 1. Valladolid en el siglo xv. Fuente: elaboración propia a partir del que aparece en Rucquoi (1983) y de la información contenida en Álvarez Mora (2005).

La refundación de la ciudad tuvo que esperar a que comenzara la Baja Edad Media, cuando los reinos cristianos del norte iniciaron su expansión definitiva hacia el sur, más allá de la cordillera Cantábrica, y comenzaron a promover la fundación de nuevos asentamientos con el fin de atraer y fijar a gentes de otros lugares para que colonizaran los territorios incorporados a sus dominios. Entre los siglos x y XI nacieron de esta forma la mayor parte de las actuales ciudades castellanas; pero Valladolid fue una excepción, pues su resurgimiento no estuvo vinculado a la voluntad real, fue espontáneo, sin que mediara el otorgamiento previo de un fuero o cualquier otro documento fundacional (Rucquoi, 1982, p. 77).

El topónimo «Valladolid» aparece por primera vez en 1062 (Valdeón Baruque, 1999, p. 182) para referirse a un asentamiento murado ${ }^{5}$ que se había construido en las inmediaciones del antiguo poblado visigodo, pero no exactamente en el mismo lugar, sino al norte de la Esgueva septentrional. El centro y origen del recinto era la parroquia de San Miguel, hoy desaparecida, que se situaba en la plaza homónima; a su alrededor habían nacido otras ermitas en torno a las cuales surgieron dis-

\footnotetext{
${ }^{5}$ Esta cerca data de mediados del siglo XI. El centro del recinto era la plaza de San Miguel y su perímetro puede seguirse a través del trazado de las calles abiertas en los baldíos surgidos del derribo de sus antiguos lienzos. Comenzando en la corredera de San Pablo continuaba hacia el sur y atravesaba la plazuela de las Angustias; a la altura del Teatro Calderón giraba hacia el oeste por la calle Cantarranas y la margen derecha del brazo septentrional del Esgueva, y finalmente se dirigía hacia el norte hasta alcanzar el puente Mayor.
} 
tintos barrios, que posteriormente fueron rodeados por la cerca (Torres Balbás, 1987, p. 102). El muro limitaba a mediodía con el Esgueva y a poniente con el Pisuerga, que se encontraba a una cierta distancia para evitar posibles riesgos de inundaciones. Pero el primer documento conocido que se refiere directamente a Valladolid data de mayo de 1095, el año en el que el conde Ansúrez dotó oficialmente de posesiones y rentas a la colegiata de Santa María, que él mismo había fundado (Rucquoi, 1982, p. 77). También mandó construir extramuros otros edificios que más tarde se constituirían en emblemas de la ciudad, como su propio palacio o las iglesias de Santa María (1095), hoy catedral, y la Antigua. Más tarde, para incluir a éstos en el perímetro murado, ordenó levantar una nueva cerca que también incluyó, por primera vez en la historia de la ciudad, un tramo de Esgueva; finalmente el nuevo espacio intramuros acogió una nueva parroquia, la de San Martín, que fue erigida una vez concluidas las obras del muro.

\section{EL RÁPIDO CRECIMIENTO DE LOS SIGLOS XII Y XIII}

La ciudad del conde Ansúrez pronto se convirtió en una de las principales de Castilla; más aún después de que Alfonso VI conquistara Toledo en 1085, pues este acontecimiento reforzó las ventajas heredadas de su posición en el centro de la cuenca del Duero. Con la conquista de la ciudad del Tajo el camino que desde ésta se dirigía a Burgos se consolidó como el principal eje meridiano de comunicaciones del norte peninsular, y Valladolid, en posición equidistante de Burgos y Toledo, en el centro neurálgico de los intercambios entre las principales ciudades castellanas (Álvarez Mora, 1994, p. 268). Tan ventajosa situación impulsó una rápida diversificación de sus funciones y ésta, a su vez, una etapa de bonanza económica y urbanística que se prolongó hasta finales del siglo XIII (Valdeón Baruque, 1999, p. 183).

Causa fundamental del desarrollo económico fue la llegada a la ciudad de numerosas y variadas instituciones, algunas de ellas con una capacidad de irradiación que superaba ampliamente el marco local. Era el caso de las dos ferias ${ }^{6}$ que le fueron concedidas en 1156 y en $1263^{7}$, y también de la universidad. Aunque los orígenes de ésta

\footnotetext{
${ }^{6}$ En esta época las ferias desempeñaban un papel económico fundamental, pues eran el centro neurálgico del comercio a escala regional e internacional (Pirenne, 1974, pp.75-80; Cameron, 1992).

${ }^{7}$ La de 1165 fue la primera de Castilla; la segunda le fue otorgada por Alfonso V (Rucquoi, 1982, p. 22)
}

son inciertos ${ }^{8}$, se sabe que al menos estaba abierto un studium, impulsado probablemente por Alfonso X, antes de que terminara el siglo XII; pero su conversión en auténtica universidad sólo se produjo en 1346, después de que el papa Clemente VI le concediese su bula (Valdeón Baruque, 1989, pp. 20-23). Desde sus orígenes ofreció estudios de teología y medicina y a ella acudían estudiantes de toda Castilla y también de otros reinos peninsulares.

A finales del siglo XIII, durante el reinado de Sancho IV, la ciudad también acogió en numerosas ocasiones la Corte (Gutiérrez Baños, 1999, pp. 71-72) y, además, comenzó a gestarse en esta época una de las principales funciones desempeñadas por la ciudad durante el Antiguo Régimen: la de gran centro religioso. A las instituciones eclesiásticas ya existentes se les sumaron en esta época numerosos edificios religiosos. En 1288 eran ya trece las parroquias de la ciudad (Valdeón Baruque, 1999, p. 183) y se habían asentado nuevos conventos y monasterios; los primeros de un conjunto que no se completaría hasta finales del siglo XVII. De los más antiguos fueron las Huelgas Reales y Santa Clara, abiertos en 1247, a los que siguieron el de San Francisco (1260), en el flanco meridional del recinto de la plaza Mayor; el de San Pablo (1261), de los dominicos, frente a la principal puerta de acceso a la ciudad desde el norte, y los de Trinitarias y Mercedarios, situados al sur. Algunos de ellos, como el de San Pablo, o el de San Francisco, llegaron a desempeñar un papel muy relevante en el seno de sus congregaciones y también en la historia de la ciudad. Ambos alojaron muchas veces a los reyes de Castilla durante sus estancias en la ciudad, y en el segundo llegaron a reunirse las sesiones del Consejo Municipal (Álvarez Mora, 2005, p. 55).

Las ferias, la universidad, la Corte y los conventos activaron la vida económica y cultural de Valladolid, convirtiéndose en soporte de un dinamismo económico que aceleró el crecimiento demográfico. La ciudad atrajo a gentes venidas de los reinos cristianos de todo el norte peninsular y surgieron las primeras colonias de profesores, comerciantes y estudiantes, así como las de artesanos que trabajaban para el mercado local.

Fruto de la vitalidad económica e institucional, así como del propio crecimiento demográfico, fue una importante expansión urbana. El antiguo recinto murado se colmató y la ciudad se expandió extramuros de la cerca

\footnotetext{
${ }^{8}$ Existen defensores de hasta tres hipótesis distintas para explicar el origen de la universidad: el traslado a la ciudad de la primigenia Universidad de Palencia; un estudio particular creado por el conde Ansúrez en la abadía de Santa María la Mayor, y su fundación directa por parte del rey y del municipio (Sánchez Movellán, 1989, pp. 25-30)
} 
del conde Ansúrez, preferentemente hacia el sur, para ocupar los terrenos que todavía permanecían baldíos entre las dos Esguevas. En 1095 (Álvarez Mora, 1994, p. 268) comenzó a utilizarse para celebrar el mercado un espacio abierto situado en ese lugar, frente a la puerta de la muralla que conducía a la parroquia de San Miguel; la misma en la que terminaba el camino de Simancas una vez atravesado el puente sobre el río. Un espacio, por tanto, privilegiado, que servía de nexo y lugar de intercambio entre el mundo rural y el urbano, en el que, además, los mercaderes evitaban el pago de los portazgos. Su fisonomía fue cambiando con el tiempo a medida que adquiría nuevas funciones o acogía acontecimientos como las ferias o el mercado y, a principios del siglo XIV, se extendía por el amplio espacio de forma triangular que hoy ocupan la plaza Mayor y su entorno porticado.

Para integrar en el tejido urbano las nuevas edificaciones surgidas extramuros, se proyectó una nueva cerca ${ }^{9}$ cuyas obras se iniciaron a finales del siglo XIII y concluyeron en la tercera década del siglo xIV. Su perímetro delimitaba una superficie aproximada de ciento cincuenta hectáreas, cuatro veces mayor que la de la vieja ciudad murada, que incluía la parte de la Esgueva septentrional que discurría entre la antigua cerca y su desembocadura. Este hecho obligó a levantar nuevos puentes para facilitar la comunicación entre las dos vertientes del río, como el que serviría de acceso directo entre San Miguel y la plaza del mercado.

Terminada la construcción de la cerca, el nuevo recinto urbano, delimitado ahora por la Esgueva meridional, adquirió una amplitud suficiente para absorber el crecimiento demográfico durante los dos siglos posteriores.

\section{LA TRANSFORMACIÓN URBANA DE LOS SIGLOS XV Y XVI}

El siglo XIV no fue fácil para la ciudad; como en otros lugares de España y de Europa, proliferaron las crisis po-

\footnotetext{
${ }_{9}$ La tercera cerca se levantó entre los últimos años del siglo XIII y los primeros del XIV (Rucquoi, 1982, p. 22). Partiendo del puente Mayor, discurría unos doscientos metros hacia el norte, paralela al Pisuerga, hasta la Rondilla de Santa Teresa. Aquí tomaba dirección sureste hasta el palacio de la Chancillería, donde realizaba un quiebro hacia el oeste, dejando al sur el actual Hospital Clínico. Continuaba hacia el sureste por Ramón y Cajal hasta el convento de las Huelgas Reales y allí giraba hacia el sur por la plaza de Don Juan y la calle de Don Sancho. Llegada a la calle Tudela, se dirigía al oeste por las calles Manterías, Claudio Moyano y Doctrinos, y al final de ésta se orientaba bruscamente hacia el norte para alcanzar el puente Mayor. En este último tramo discurría por la terraza superior del Pisuerga, cerca de la ladera que descendía hasta el río Pisuerga. A partir de 1784, derruida la cerca ocupó su lugar los jardines de las Moreras, una iniciativa de la Sociedad Económica de Amigos del País, y años más tarde el paseo de Isabel la Católica.
}

líticas, económicas y demográficas. Pero comenzado el siglo xv la ciudad entró en una fase expansiva que culminó a mediados del siglo xvi bajo el reinado de Felipe II. En ese momento alcanzó el mayor esplendor de su historia, tanto en el ámbito político como en el económico o el social.

\section{A) Las bases económicas y demográficas}

La etapa de prosperidad se inició a mediados del siglo xv con la dinastía castellana de los Trastámara, en especial con Juan II y Enrique IV, continuó con los Reyes Católicos y alcanzó su máximo esplendor con los dos primeros Austrias, Carlos I y Felipe II. Fue una época en la que Valladolid gozó del favor real y del privilegio de ser una de las sedes itinerantes de la corte, por lo tanto capital circunstancial de los reinos de España, lo que le sirvió para desarrollar una vitalidad económica, demográfica y urbana sin precedentes (para esta época, véase Bennassar, 1967).

En 1452 Juan II, oriundo de la ciudad, la distinguió con la concesión de la única chancillería del reino de Castilla ${ }^{10} \mathrm{y}$, lo que es más importante aún, la eligió como una de las sedes itinerantes predilectas de su Corte ${ }^{11}$, la única situada al norte del Sistema Central. Enrique IV le otorgó en 1464 el derecho a celebrar mercado todos los martes, para lo que se eligió el amplio espacio abierto ante la principal puerta meridional de la ciudad, al otro lado del Esgueva (Rucquoi, 1982, p. 12); y, además, la mantuvo como una de sus sedes predilectas. Los Reyes Católicos la ratificaron en 1489 como sede de la Chancillería, si bien dejó de ser única en 1494, cuando los mismos reyes crearon una segunda con sede en Ciudad Real y jurisdicción sobre las tierras situadas al sur del Tajo, que más tarde (1505) fue traslada a Granada en 1505, por orden firmada por la reina Juana (Coronas González, 1998, pp. 61-78). Por último, los primeros Austrias no dotaron a la ciudad de ninguna nueva institución, pero prolongaron sus estancias en ella hasta convertirla en su capital de facto $^{12}$.

\footnotetext{
${ }^{10}$ La Chancillería era en esta época la suprema jurisdicción ordinaria civil y penal del reino. En ausencia del rey ocupaba el primer puesto en el ceremonial público (Martín González, 1981, p. 140).

${ }^{11}$ Durante las últimas décadas de la Edad Media los reyes de Castilla no dispusieron de una sede fija, residiendo la Corte allí donde se encontraba el rey. Carlos I, el último rey itinerante, dispuso de alcázares en Madrid, Toledo y Sevilla, además del palacio de Granada mandado construir por él mismo (Rivera Blanco y Pérez Gil, 2002, pp. 13-66).

${ }_{12}$ Entre 1527 y 1559 la ciudad fue sede de la Corte con la única excepción del tiempo transcurrido entre 1536 y 1543 (Ribot García, 1981, pp. 14-15).
} 
La fase álgida de este periodo se inició con el reinado de Carlos I y se prolongó hasta los primeros años del reinado de Felipe II, un rey nacido en la ciudad que, sin embargo, certificó en 1559 el inicio de su declive al elegir a Madrid como capital única y permanente de los reinos de España. En esta época las antiguas instituciones (ferias, universidad...), junto a las de nueva creación (Corte, Chancillería, tribunal del Santo Oficio, mercado semanal), fomentaron el desarrollo económico, demográfico y político. La Chancillería y la universidad atrajeron a un ejército de letrados, profesores y estudiantes que se unió al formado por los comerciantes de toda la Península, e incluso del extranjero, que cada vez en mayor número llegaban a la ciudad atraídos por sus ferias. Pero, sin duda, el elemento determinante de la revitalización fue la Corte. Ésta no sólo atrajo a cortesanos, criados y personas que buscaban un trabajo en la administración; también a artesanos que producían artículos de lujo, sobre todo paños, y a nuevas órdenes religiosas que con su presencia reforzaron la función eclesiástica adquirida siglos atrás. Valladolid se convirtió entonces en una de las grandes metrópolis peninsulares y en la tercera en importancia del reino de Castilla, tras Sevilla y Toledo, tanto por su número de habitantes como por su tamaño o por su importancia política. En 1521 alcanzaba los 6.700 vecinos, que según estimaciones razonables, suponía una población cercana a los 31.000 habitantes (Ribot García, 1981, pp. 18-19), y en 1559, el año del traslado de la Corte a Madrid, la cifra de vecinos se elevaba hasta los 7.547 vecinos (unos 35.000 habitantes). A partir de ese momento la evolución demográfica se resintió y en los veinte años posteriores perdió en torno al veinte por ciento de su población (Rucquoi, 1982, pp. 35-52; Bennassar, 1981, p. 73, y Ribot García, 1981, pp. 18-19). Ahora bien, Bennassar (1981, p. 87) argumenta que con posterioridad, y hasta finales de siglo, una parte de las pérdidas se recuperaron gracias al dinamismo y la solidez de algunas de sus instituciones, como la universidad y la Chancillería. El declive definitivo sólo se iniciaría, al igual que en el resto de Castilla, durante los últimos años del siglo, coincidiendo con una época de malas cosechas, carestía del cereal y episodios pestilentes.

\section{B) La expansión urbana del siglo XVI}

A expensas del desarrollo económico y demográfico, la ciudad conoció en esta época un ritmo edificatorio sin precedentes. Aparecieron nuevos barrios, sobre todo al sur, y se levantaron numerosos edificios singulares (palacios, iglesias, conventos, sedes de instituciones, etcétera)

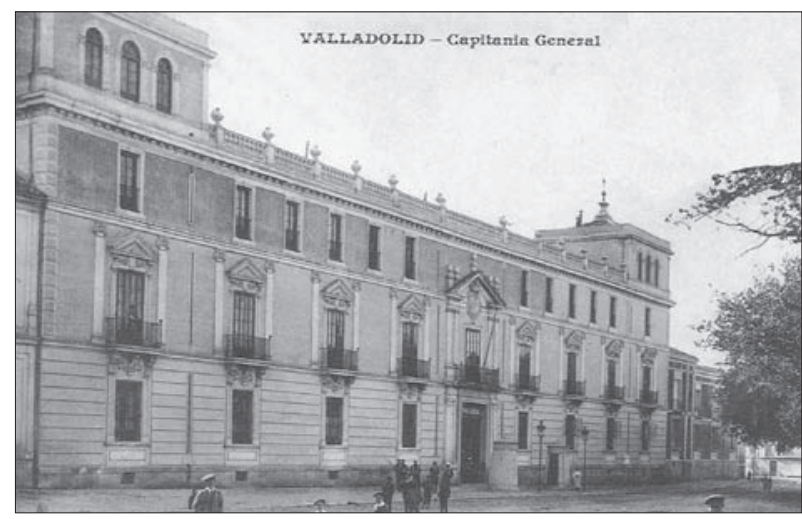

FIG. 2. El Palacio Real, uno de los más destacados arquitectónicamente de Valladolid, tuvo su origen en el que comenzó a construir don Francisco de los Cobos hacia 1522. En 1600 los marqueses de Camarasa se lo vendieron al duque de Lerma que fue quien, en 1601, trasladada la Corte a Valladolid, se lo vendió al rey Felipe III (1601) para que le sirviera de residencia (Rivera Blanco y Pérez Gil, 2002).

que, junto a los ya existentes, dotaron a la ciudad de un patrimonio arquitectónico de gran valor.

Entre los edificios institucionales destacaban la universidad, el palacio de Santa Cruz, la Chancillería, el colegio de San Gregorio, el palacio del Santo Oficio o la casa de beneficencia, todos ellos en el centro de la ciudad. Por su parte, los palacios erigidos por las casas nobiliarias y los grandes comerciantes se ubicaban preferentemente en la mitad septentrional y alcanzaban su mayor densidad en el entorno de la corredera de San $\mathrm{Pa}-$ blo (Martín y González, 1981, p. 156), donde se situaban dos de los edificios preferidas por los reyes cuando residían en la ciudad, el convento de San Pablo y el palacio del Duque de Medinaceli, posteriormente convertido en Palacio Real. En este mismo entorno se encontraban el palacio del Conde de Benavente, más tarde convento de Trinitarias; el del Almirante, cuyo solar hoy ocupa el Teatro Calderón; el de los Condes de Ribadavia, erigido durante el primer tercio del siglo (Urrea, 1996, p. 137), ocupado actualmente por la Diputación, o los de López de Mendoza, Marqueses de Távara o Marqués de Villena.

Pero el conjunto de edificios con mayor presencia urbana era el eclesiástico. Los templos parroquiales eran más de veinte, entre los que sobresalían San Martín, la Antigua, la Vera Cruz y la catedral, esta última levantada sobre la fábrica de la vieja iglesia de Santa María. El número de conventos y monasterios era aún mayor y muchos de ellos eran imponentes, tanto por su tamaño como por su valor arquitectónico o por su influencia religiosa, irradiada mucho más allá de los límites de la ciudad. A 


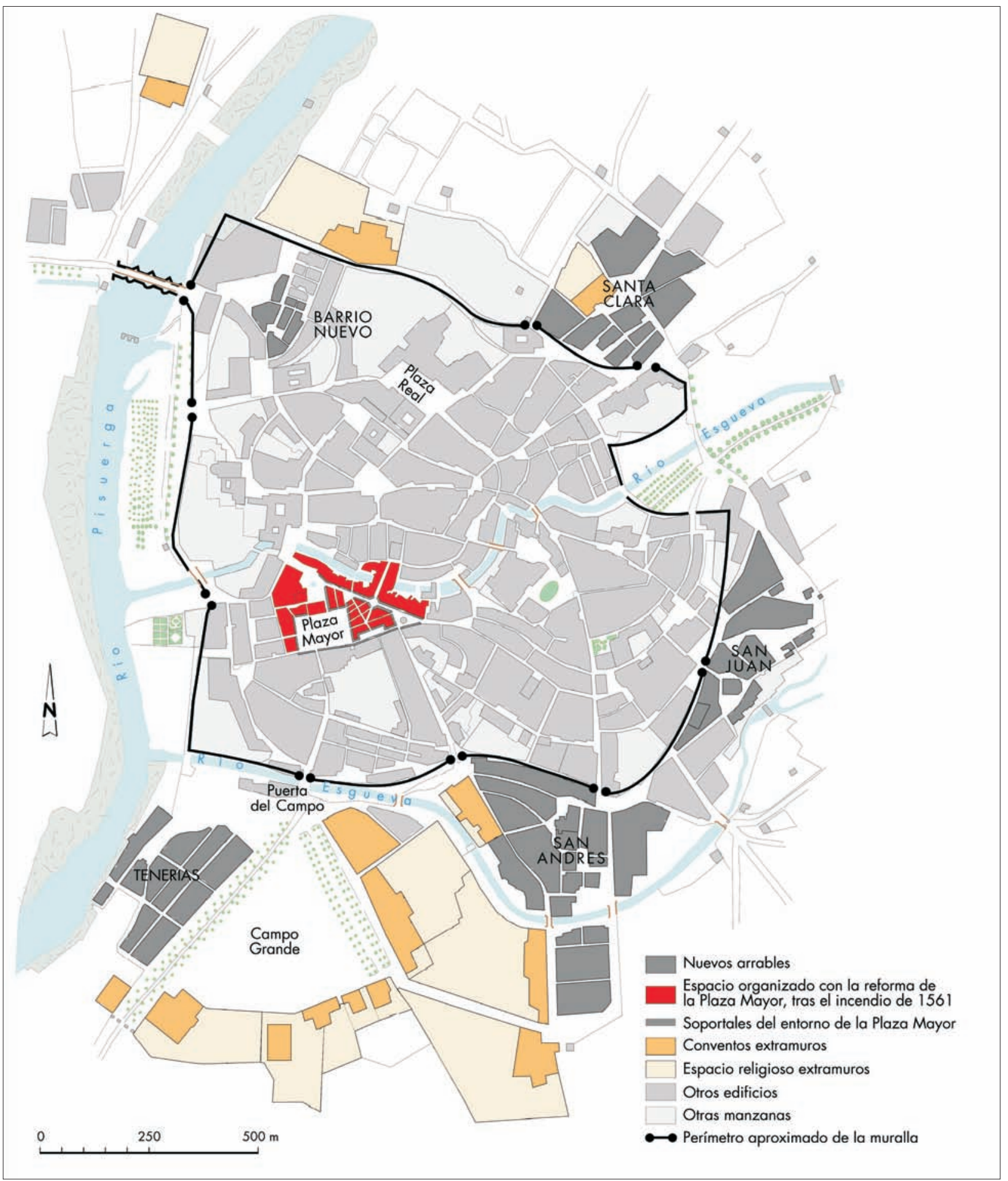

FIG. 3. Expansión urbana y reforma interior en el Valladolid del siglo xvi. Fuente: elaboración propia a partir del plano de Valladolid de F. Marrón (1839). También se ha utilizado la información del plano de Bentura Seco (1738), del que aparece en Rucquoi (1983), así como otro tipo de información documental. 
los ya existentes se les unieron en esta época, entre otros, el de San Benito, uno de los más importantes ${ }^{13}$, fundado por Juan I en 1390 y levantado sobre el solar del viejo Alcázar; el de los Jerónimos (1440), en la margen derecha del Pisuerga; el de de Santa Catalina, de las dominicas (1488), o el de Santa Isabel, de las clarisas (1488). Pero fue sobre todo durante los siglos XVI y también XVII cuando se dio la mayor proliferación. Entre 1521 y 1670 se levantaron otros veinticinco nuevos conventos (Álvarez Mora, 1994, p. 272).

Las nuevas edificaciones contribuyeron a cambiar el ornato y la forma urbana. El ornato, por la cantidad y magnificencia de los edificios erigidos; la forma, porque una parte de los nuevos edificios sirvió para consolidar el espacio intramuros y otra para expandir la mancha urbana mucho más allá de los límites de la última cerca construida. La superficie de la ciudad se duplicó y a mediados del siglo xvi había alcanzado las trescientas hectáreas, prácticamente la misma que tendría trescientos años más tarde.

La expansión se produjo en todas las direcciones, tanto dentro del recinto murado como fuera de él. En el interior surgió un barrio nuevo, al sur de la judería, cuyo principal eje viario, la calle Imperial (Bennassar, 1981, pp. 73-74), permitía un fácil acceso desde la parte más noble de la ciudad, la corredera de San Pablo, hasta el puente Mayor. Extramuros, por su parte, se consolidaron como barrios algunos núcleos surgidos frente a las principales puertas de acceso, como los de Santa Clara, al noreste, y el de San Juan, a levante. Pero la expansión urbana más notable fue la que se produjo hacia el sur, sobrepasando por primera vez el límite natural impuesto por la Esgueva meridional. Aquí surgió, a principios del siglo xIV (Fernández de Diego, 1971, p. 12), el barrio artesano de San Andrés, al sureste, y, en las inmediaciones del Pisuerga, el de Tenerías, donde se concentró la artesanía del curtido de pieles. Además, se instalaron, entre ambos barrios, un buen número de los nuevos conventos, en concreto nueve de los veinticinco construidos a partir de 1521 (Ribot García, 1981, pp. 19-26).

Los nuevos conventos junto con el barrio de Tenerías dieron límites precisos al denominado Campo Grande, un amplio espacio abierto al sur de la puerta del Campo, en el que confluían los caminos que se dirigían a las principales ciudades del sur (Madrid, Ávila, Segovia, Toledo).

${ }^{13}$ El convento de San Benito, por ejemplo, llegó a unir bajo su obediencia a todos los conventos benedictinos españoles, excepto los del reino de Aragón, al tiempo que llevaba su influencia hasta Portugal, Austria, América e Inglaterra (Rodríguez Martínez, 1981, p. 279).

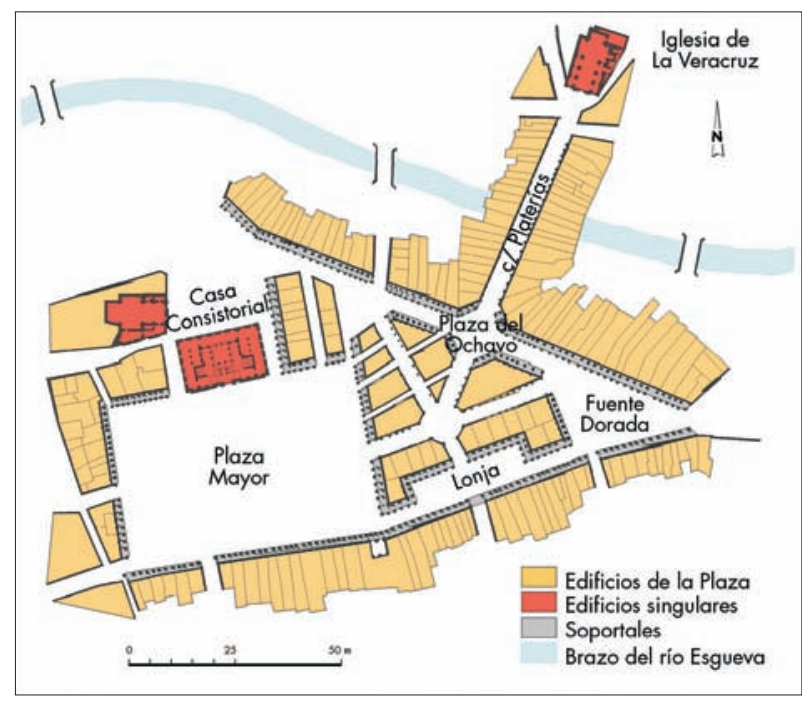

FIG. 4. Proyecto de reedificación del centro de Valladolid de Francisco de Salamanca (1561). Fuente: elaboración propia a partir del plano que aparece en Altés Bustelo (1998).

Con las nuevas construcciones el Campo Grande adquirió la forma triangular que aún posee y, además, el carácter de principal espacio ceremonial de la ciudad (Álvarez Mora, 1994, pp. 268-271). Flanqueado al sur y a levante por los conventos y a poniente por el barrio de las Tenerías, este espacio servía de entrada monumental a la ciudad desde el sur, al tiempo que desempeñaba la función de lugar de recreo, paseo y diversión para los habitantes. También albergó otras actividades, como la celebración de ejecuciones públicas o el mercado de ganados).

Ahora bien, la pieza urbanística más destacada de esta época fue, sin duda, el conjunto formado por la plaza Mayor y su entorno porticado. Un conjunto cuya fisonomía actual comenzó a gestarse en la segunda mitad del siglo Xvi (Calderón Calderón, 2007), después de que la antigua plaza del mercado fuera asolada por un incendio devastador que arruinó 440 casas, pues a raíz de éste el Consistorio encargó un proyecto de reconstrucción a Francisco de Salamanca (Álvarez Mora, 1994, p. 270), fruto del cual surgió el conjunto urbano que hoy conocemos.

El arquitecto concibió un espacio de gran tamaño, que cumpliera las funciones de espacio representativo y comunitario (Álvarez Mora, 2005, p. 57). El elemento central era una plaza rectangular $(120 \times 80 \mathrm{~m})$ y uniforme, de morfología unitaria y toda ella rodeada de edificios con amplios soportales. Para conseguir la unidad morfológica, Francisco de Salamanca fijó las normas por las que debían regirse las edificaciones que rematarían sus costados: serían de cinco alturas, la inferior porticada 


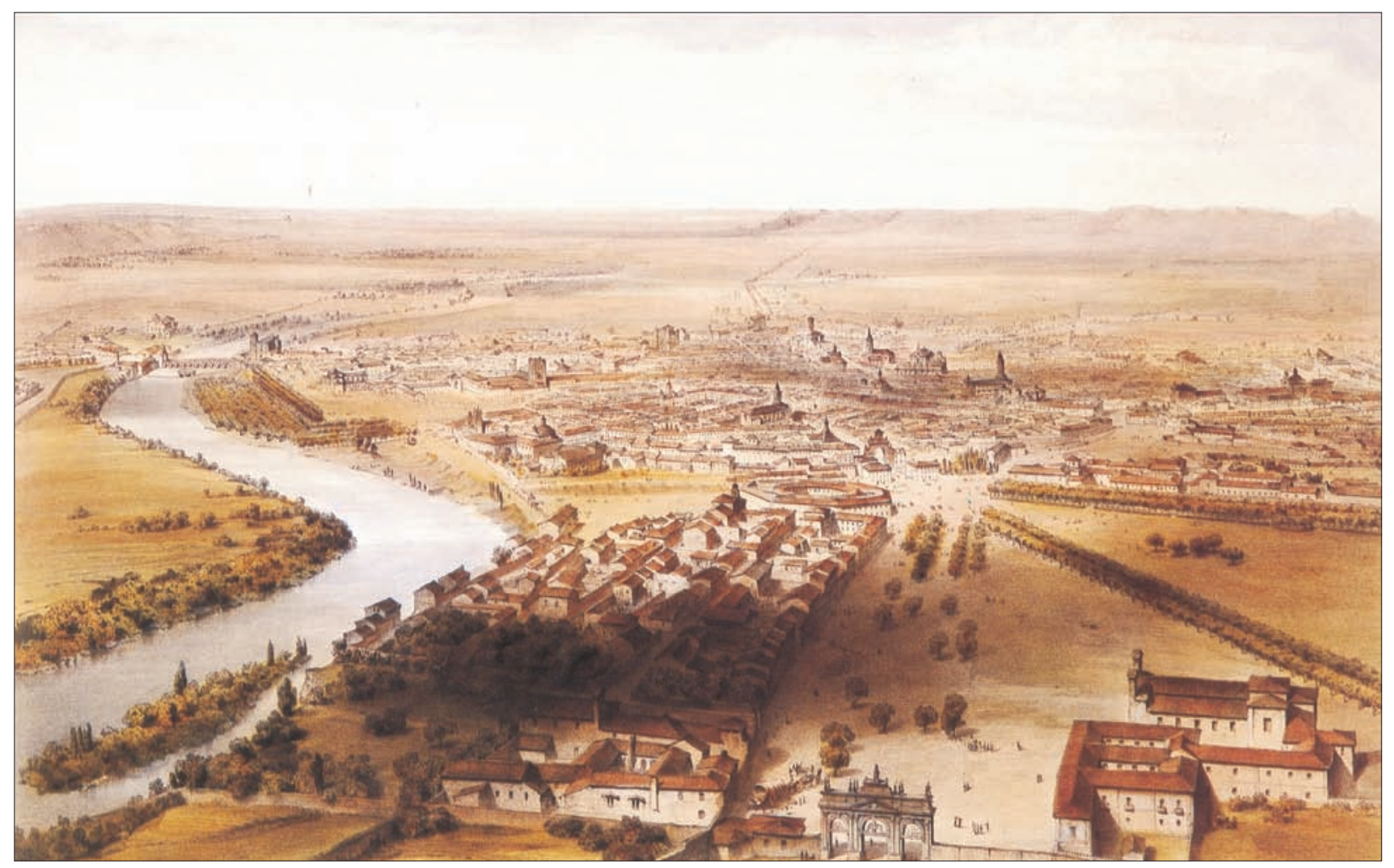

FIG. 5. La vista de Valladolid realizada por Alfred Guesdon a mediados del siglo XIX constituye un documento excepcional para percibir la ciudad construida a lo largo del Antiguo Régimen: su tamaño, los baldíos, el protagonismo de los edificios eclesiásticos o el imponente espacio ceremonial del Campo Grande.

y la superior abuhardillada; materiales y colores uniformes en sus fachadas, y proporciones constantes entre su altura y el tamaño de sus soportales (Calderón Calderón, 2007, pp. 107-134). Los soportales, además de magnificar el conjunto, también cumplían otras funciones, como proteger de las inclemencias del tiempo a los paseantes y cobijar a los comerciantes en los días de mercado (Altés Bustelo, 1998). La uniformidad edificatoria ${ }^{14}$ sólo se vería alterada por un edificio, la casa consistorial, que, como representación máxima del poder ciudadano, debería presidir el conjunto monumental (Cervera Vera, 1978, pp. 191-192). Pero el proyecto incluía también el diseño de la trama del espacio porticado circundante, que comprende, además de la plaza Mayor, las del Ochavo, Fuente Dorada, Corrillo y Rinconada; así como las calles de la Lonja, de la Cebadería y de Platerías. Se trata, en suma, de un interesantísimo conjunto urbanístico, tanto

${ }^{14}$ La uniformidad arquitectónica de la plaza, que no de todo el conjunto, es un hecho excepcional en esta época. De hecho, se adelanta en casi cincuenta años a otras plazas regulares españolas y también europeas, como las de Madrid, Charleville, Los Vosgos (París) o Covent Garden (Londres) (Bonet Correa, 1978, p. 52). por su belleza como por su originalidad, primero en su género en España (Martín González, 1981, p. 152), que posteriormente sirvió de modelo para diseñar otras plazas mayores españolas, como las de Madrid o Salamanca (Cervera Vera, 1987, p. 200).

La expansión urbana de esta época culminó con el derribo de la cerca del siglo XIV, solicitada por distintas instancias, que argumentaban acerca de su inoperancia tanto militar como fiscal, y la construcción de otra nueva, que incorporara al recinto intramuros los nuevos barrios y monasterios surgidos extramuros durante los dos siglos anteriores. Las obras de la nueva cerca se iniciaron en 1619.

\section{El LaRgo declive de LA CiUdAd A FINALES DEL ANTIGUo RÉGimen}

La prolongada etapa de prosperidad vivida por Valladolid desde la llegada al poder de los Trastámara se vio truncada de una forma muy brusca en octubre de 1559 , el año en el que Felipe II decidió trasladar la corte a Madrid (Bennassar, 1981, p. 76) para convertirla en capital 
FIg. 6. Valladolid. El espacio palaciego a fines del Antiguo Régimen (1839). Fuente: elaboración propia. El plano es una aproximación realizada sobre la base del plano de

Valladolid de F. Marrón (1839). También se ha tenido en cuenta, entre otras, la información contenida en el plano de Bentura Seco (1738), en Álvarez Mora (2005) y en Urrea (1996).

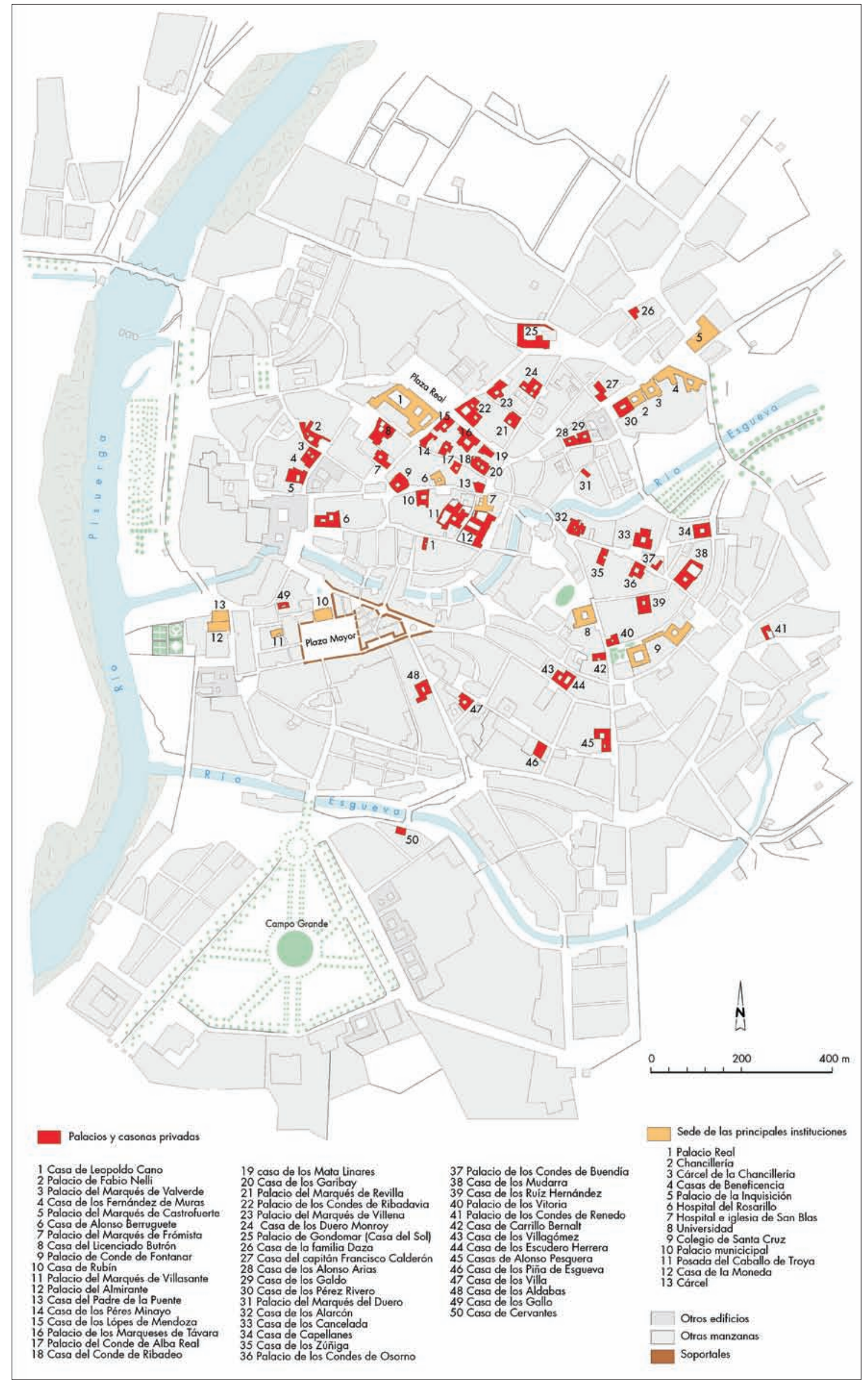




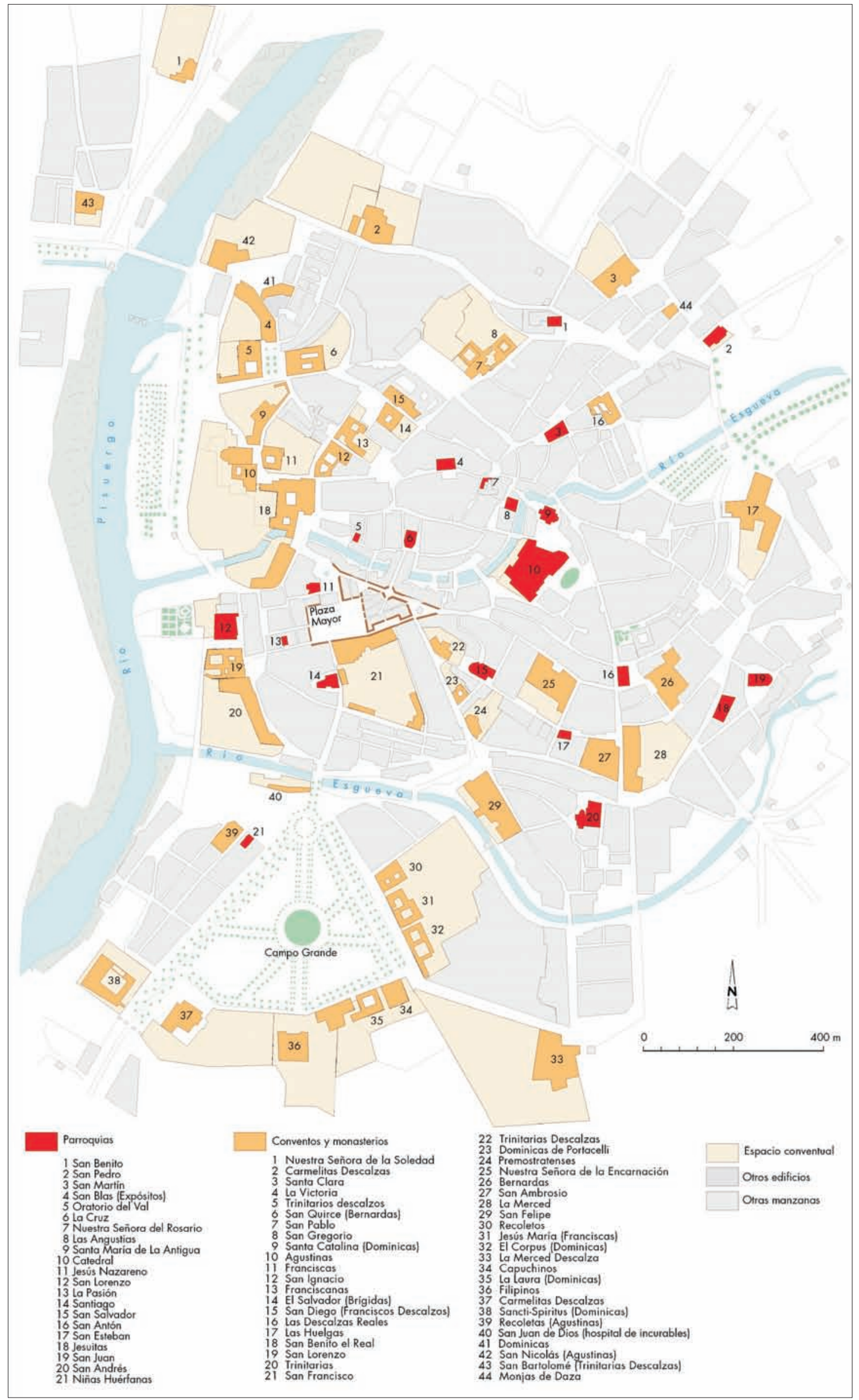

FIG. 7. Valladolid. el espacio religioso a fines del Antiguo Régimen (1839). Fuente: elaboración propia. El plano es una aproximación realizada sobre la base del plano de Valladolid de F. Marrón (1839). También se ha tenido en cuenta, entre otras, la información contenida en el plano de Bentura Seco (1738) y en Álvarez Mora (2005). 
única de sus reinos. La salida de la Corte supuso la de los cortesanos, las grandes casas señoriales, los funcionarios y todo el séquito de personas que vivía de su cercanía, lo que conllevó una importante sangría demográfica y la pérdida de rentas fundamentales para el mantenimiento de la producción artesana. El descenso de la población fue enorme y en 1575 ya se contabilizaban 562 casas vacías (Iglesias Rouco, 1978, p. 19) muchas de ellas en los barrios San Andrés, San Juan o la Magdalena (Calderón, Mata y Sáinz, 1982, p. 25). La ciudad entró entonces en una larga etapa de atonía de la que no se recuperaría hasta las primeras décadas del siglo XIX.

La pérdida de la sede regia fue sin duda el elemento determinante del declive de la ciudad, como su llegada lo había sido antes de su prosperidad; sin embargo, durante las últimas décadas del siglo xvi todavía gozó de cierto dinamismo gracias a la vitalidad de sus principales instituciones, como la universidad o la Chancillería. También pasó por una breve etapa de esplendor a principios del siglo XVII, durante los seis años (1601-1606) en los que Felipe III fijó de nuevo su residencia en Valladolid. Uno de los principales promotores del retorno de la Corte a la capital del Pisuerga fue el valido del rey, el duque de Lerma, que fue quién le proporcionó al rey, previo pago de una elevada suma de dinero, el que desde ese momento se convertiría en Palacio Real ${ }^{15}$. Durante esta etapa el rey y su Corte fueron un estímulo muy importante para el desarrollo económico y el desarrollo demográfico, y según algunos autores superó en esta época los sesenta mil habitantes, la cifra más elevada antes de la industrialización. Ahora bien, una vez que la corte fue de nuevo traslada a Madrid, la ciudad entró en una crisis de la que prácticamente no se recuperaría hasta mediados del siglo XIX (Gutiérrez Alonso, 1989, pp. 82-90).

La crisis económica y demográfica, agravada a partir de 1609 con la expulsión de los moriscos, paralizó también el desarrollo urbano, de manera que los rasgos fundamentales de su morfología y sus límites se mantuvieron durante algo más de doscientos años. Los planos de Bentura Seco (1738) y de Francisco Marrón (1839) son una buena prueba de ello.

El primero de ellos, en el que se incorpora el alzado de los edificios, representa una buena muestra de la per-

${ }^{15}$ El Palacio Real, uno de los más destacados arquitectónicamente de Valladolid, tiene su origen en el que comenzó a construir don Francisco de los Cobos hacia 1522. En 1600 los marqueses de Camarasa se lo vendieron al duque de Lerma, que fue quien, en 1601, trasladada la Corte a Valladolid, se lo vendió al rey Felipe III (1601) para que le sirviera de residencia (Rivera Blanco y Pérez Gil, 2002, pp. 13-66). manencia de los rasgos de la ciudad renacentista. Entre ellos el trazado de la última cerca, levantada con fines fiscales a partir de 1619 (Álvarez Mora, 2005, p. 50). Partiendo del camino de Cabezón, el muro seguía una dirección prácticamente meridiana, atravesaba la puerta de Tudela (plaza Circular) y el brazo meridional del Esgueva, para más tarde girar hacia el oeste y dirigirse hacia el Pisuerga, dejando dentro de su perímetro los numerosos conventos que en épocas precedentes se habían levantado en los frentes oriental y meridional del Campo Grande.

También eran perceptibles las características de la trama, muy distintas al norte y al sur de la Esgueva meridional. Al norte de su cauce, la trama era compleja y caótica, fiel heredera del crecimiento orgánico; las calles, estrechas, cortas, sinuosas y quebradas, y las manzanas, muy heterogéneas e irregulares. Además, los espacios abiertos eran escasos, si bien destacaba la amplitud de sus principales plazas: la de San Pablo, la Mayor y la del Campillo (España). La más antigua era la de San Pablo, al norte, nacida frente a la puerta que daba entrada al primer recinto murado desde el camino de Cabezón a través de la calle del León. Durante la etapa de esplendor se convirtió en el centro neurálgico del poder político y espacio residencial preferente de la clase dominante lo que la convirtió en uno de los conjuntos urbanísticos más monumentales de la ciudad. Aquí se encontraban el convento de los dominicos (San Pablo), el colegio de San Gregorio y algunos de los más destacados palacios vallisoletanos, como el Palacio Real (Capitanía General), el del Conde de Miranda (convertido en sede de Hacienda y más tarde derruido), el de los Condes de Ribadavia, casa natal de Felipe II, hoy convertida en sede de la Diputación, y el de los López de Mendoza. Por antigüedad la segunda de la plazas era la Mayor, cuyos origen y funciones ya hemos comentado, y la más reciente la del Campillo. Como las dos anteriores, había nacido frente a una de las puertas de la muralla; en este caso la más meridional de las abiertas en la muralla del siglo XIV, ocupando el baldío que se extendía entre ella y la Esgueva meridional.

Al sur del Esgueva, en la parte más moderna, los rasgos de la trama eran bien distintos. Destacaban, a poniente, la regularidad de la trama del barrio de las Tenerías, sin duda trazada a cordel, cuyos orígenes desconocemos; en el centro, el espacio abierto de grandes dimensiones, inusual en la época, correspondiente al Campo Grande, principal vía de acceso a la ciudad (Fernández del Hoyo, 1981, pp. 28-31), y, a levante, la manzana que ocupaba el espacio vacante entre el Campo 
Grande y el curso del Esgueva, cuyo tamaño la convertía en la mayor de la ciudad.

El plano de Ventura Seco también nos muestra los cauces de las dos Esguevas, todavía descubiertos a lo largo de todo su recorrido, así como la localización de hasta 92 edificios religiosos, de los cuales 48 eran conventos de frailes y monjas, y diez hospitales y congregaciones.

El plano de Francisco Marrón de 1839, por su parte, sirve para corroborar que las características de la ciudad del siglo xVI, mantenidas a mediados del XVIII, todavía perduraban en la tercera década del siglo xIx, justo antes de que la ciudad comenzara de nuevo a crecer y a transformarse, a impulsos de las primeras manifestaciones industriales. Se trata, por tanto, de un plano de enorme interés, que muestra la trama urbana heredada del Antiguo Régimen justo antes de que comenzara a ser profusamente transformada, en el que todavía son perceptibles los grandes espacios nobiliario, institucional y religioso que se formaron en aquella época. Razón por la cual ha sido utilizado como base en dos planos que sintetizan el alcance que llegaron a alcanzar las funciones nobiliaria y eclesiástica durante la Edad Moderna. En uno de los planos se han identificado los edificios civiles más relevantes de la época, en total 65 palacios, grandes casas y sedes institucionales, algunos de los cuales todavía no han sido derribados (véase Urrea, 1996); en el otro se recoge el ámbito urbano en manos de 65 instituciones eclesiásticas (21 parroquias y 44 conventos), en ocasiones propietarias de la totalidad o de gran parte de algunas de las mayores manzanas de la ciudad, como ocurría con los conventos de San Francisco, San Benito, Las Huelgas, Santa Catalina, San Pablo, La Encarnación o La Merced, por poner sólo algunos ejemplos.

\section{LA FORMACIÓN DE LA CIUDAD BURGUESA} (1840-1930)

El Valladolid que hemos tratado en las páginas precedentes, con características paradigmáticas de la ciudad del Antiguo Régimen, comenzó a transformarse con inusitada rapidez con la llegada de las primeras fábricas, a partir de 1840 . Se inició entonces el proceso de construcción de un nuevo modelo urbano, el burgués, cuya fase culminante se prolongó, aproximadamente, hasta 1930. A lo largo de esos noventa años el casco urbano heredado cambió de tamaño, de funciones y de fisonomía, y lo hizo a instancias de la burguesía, la clase social emergente de la época, que encontró en el desarrollo urbano una forma de acumulación de capital, al tiempo que una oportuni- dad para levantar nuevos espacios bien adaptados a sus necesidades de residencia, de ocio y de representación ${ }^{16}$.

\section{LAS BASES ECONÓMICAS DE LA TRANSFORMACIÓN URBANA}

En Valladolid, las causas que provocaron la sustitución del modelo urbano del Antiguo Régimen por el burgués fueron las mismas que en el resto de España: las profundas mutaciones económicas y sociales asociadas a la industrialización y al nacimiento del Estado liberal. Unas mutaciones que aquí comenzaron a sentirse en la tercera década del siglo XIX, una vez concluidas las obras de lo que fue la primera gran infraestructura moderna de la ciudad, la dársena del canal de Castilla, en cuyas inmediaciones surgieron las primeras fábricas.

El canal desempeñó un papel revitalizador para la economía de la ciudad que pronto se trasladó a la población. Después de siglos de letargo, incluso de retroceso, en los que ésta llegó a reducirse más de un tercio respecto a la de finales del siglo xvi, la población entró en una dinámica positiva que no se ha visto interrumpida, prácticamente en ningún momento, desde entonces hasta la actualidad. Bien es cierto que con ritmos que no han sido constantes, sino más bien acomodados a los vaivenes de la actividad económica.

CUADRo 1. Evolución de la población de Valladolid entre 1842 y 1940

\begin{tabular}{|c|c|c|c|}
\hline \multirow[b]{2}{*}{ Año } & \multirow[b]{2}{*}{ Población } & \multicolumn{2}{|c|}{ Incremento } \\
\hline & & Absoluto & $\%$ \\
\hline 1842 & 19.191 & & \\
\hline 1857 & 41.943 & 22.752 & 218,6 \\
\hline 1877 & 54.789 & 12.846 & 130,6 \\
\hline 1887 & 64.813 & 10.024 & 118,3 \\
\hline 1900 & 70.951 & 6.138 & 109,5 \\
\hline 1910 & 72.114 & 1.163 & 101,6 \\
\hline 1920 & 76.791 & 4.677 & 106,5 \\
\hline 1930 & 91.089 & 14.298 & 118,6 \\
\hline 1940 & 116.024 & 24.935 & 127,4 \\
\hline
\end{tabular}

Fuente: INE: Nomenclátores de la población de España (1857, 1877, $1887,1900,1910,1920,1930$ y 1940$)$.

Durante la primera etapa de la industrialización, concluida con la primera crisis ferroviaria, a principios de la

\footnotetext{
${ }^{16}$ La burguesía fue la gran impulsora y beneficiaria de los ensanches. Durante su fase de construcción fueron una importante fuente de beneficios y acumulación de capital; además, una vez concluidos, se convirtieron en su lugar preferido de residencia y en el mejor escaparate de su posición social (Capel, 1975, pp. 20-21).
} 
década de 1860, la población se multiplicó por 2,2 en tan sólo quince años, y en 1857 alcanzaba la cifra de 42.000 habitantes, superando por primera vez en su historia la que había alcanzado en el siglo XVI. El ritmo de crecimiento, aunque menor, siguió siendo elevado hasta la última década del siglo xIX, y la ciudad se acercaba en 1887 a los 65.000 habitantes.

La pérdida de las colonias y de los mercados de ultramar ralentizará de nuevo el progreso de la economía y el desarrollo demográfico (Calderón Calderón, Mata y Sáinz, 1985, pp. 7-10) y desde el último año citado hasta 1920 la población sólo aumentó en algo más de once mil personas. A partir de 1920 el crecimiento volvió a acelerarse y en tan sólo veinte años la población sumó cuarenta mil nuevos efectivos. Con esta cadencia la ciudad había logrado superar la barrera de los cien mil habitantes poco antes de iniciarse la guerra civil; una cifra que multiplicaba por seis los que albergaba tan sólo cien años antes.

\section{A) La formación del Estado liberal y la nueva división administrativa del Estado}

En España, las bases del Estado liberal se sentaron a lo largo del siglo XIX; siglo durante el cual las divisiones territoriales y jurisdiccionales del Antiguo Régimen fueron sustituidas por otras más modernas que, además, habrían de definir el reparto territorial de los órganos de gobierno del nuevo Estado.

La primera en ser aprobada y la que tuvo mayor incidencia sobre el futuro del sistema urbano fue la división provincial aprobada por real decreto de 30 de noviembre de 1833, siendo ministro de Fomento D. Javier de Burgos, pues fijó las ciudades que habrían de ser capitales de las unidades administrativas (Burgueño, 1996, pp. 291308). La capitalidad conllevaba el privilegio de ser sede única de las nuevas instituciones de gobierno dependientes de los poderes central y provincial. Pero no sólo eso, el decreto que sancionó la división provincial también preveía que fuesen las capitales provinciales las que acogiesen los órganos de gobierno de cualquier otra división administrativa que se aprobara en el futuro, como la judicial o la militar.

Valladolid fue elegida capital de la provincia homónima en 1833; desde 1843 albergó una de las capitanías generales del ejército ${ }^{17}$; y desde 1882 una de las quince

\footnotetext{
${ }^{17}$ Aunque durante el siglo XIX y las primeras décadas del xx la división militar estuvo sometida a diferentes vaivenes, las capitanías generales de algunas ciudades nunca estuvieron discutidas, entre ellas la de Valladolid (Alonso Baquer, 1985, pp. 79-82).
}

audiencias territoriales dependientes del poder judicial, con jurisdicción sobre las provincias de León, Zamora, Salamanca, y Palencia ${ }^{18}$. Al amparo de estas atribuciones comenzó a acoger desde fecha muy temprana numerosos equipamientos e instituciones de gobierno dependientes de los diferentes poderes del Estado, tanto del central (Gobierno Civil, Delegación de Hacienda, Banco de España, direcciones de Caminos, Correos, Minas o Instrucción), como del provincial (diputaciones, correccionales, hospicios, asilos de dementes, hospitales, institutos), el judicial (Audiencia, cárceles...) o el militar ${ }^{19}$ (cuarteles $^{20}$, hospital militar, parque de Artillería, Academia de Caballería...).

Todas estas instituciones pronto se convirtieron en una importante fuente de riqueza; por su capacidad de gasto y como agentes transferidores de rentas, pero no debemos olvidarnos del papel que desempeñaron en la revitalización urbana. Ésta fue importante porque ocuparon antiguos palacios y otros edificios de elevado valor histórico, que vieron así la posibilidad de ser reformados. La Diputación ocupó el palacio del Almirante y más tarde el de los Condes de Ribadavia, frente al monasterio de San Pablo; la Capitanía General se instaló primero en la casa de los Pérez Rivero y, después, en el Palacio Real; el cuartel de artillería en el palacio de Gondomar; la Audiencia en la antigua Chancillería; el hospital de dementes en el convento de Capuchinos; el manicomio en el de Nuestra Señora del Prado (Carazo Lefort, 2010, p. 38); la Escuela Normal de Maestros en el de Premostratenses; el hospital militar en el de Carmelitas calzados; el de caballería, en el de La Merced; uno de los de infantería, en el de Jesuitas; y el fuerte, en el de San Benito (Iglesias Rouco, 1978, p. 77-81).

Pero las nuevas instituciones dejaron su mayor impronta urbanística cuando actuaron como promotoras de edificios de nueva planta, generalmente de gran tamaño y significado para la ciudad, pues muchos de ellos acaba-

${ }^{18}$ La planta del poder judicial se estableció a partir de Ley Provisional del Poder Judicial (1870) y de la Ley Orgánica del Poder Judicial (1882). En ellas se diseñaron las demarcaciones que estuvieron vigentes hasta la aprobación de la Constitución de 1978. Establecían un único órgano de gobierno con jurisdicción sobre todo el territorio nacional (el Supremo Tribunal de Justicia, con sede en Madrid) y quince audiencias territoriales, una de las cuales era la de Valladolid (Díaz Valcárcel, 1985, p. 63).

${ }^{19}$ Las capitanías generales fueron muy importantes para las ciudades que las acogieron. La nueva organización del ejército, con tropa procedente del reclutamiento forzoso y universal y mandos salidos de las academias, concentró en ellas un gran número de soldados y militares que conformó un gran contingente permanente de población flotante.

${ }^{20}$ La ciudad llegó a contar con cuatro cuarteles de infantería (San Ambrosio, San Ignacio, San Pedro y Milicias), además de los de caballería y artillería (Iglesias Rouco, 1978, p. 79). 


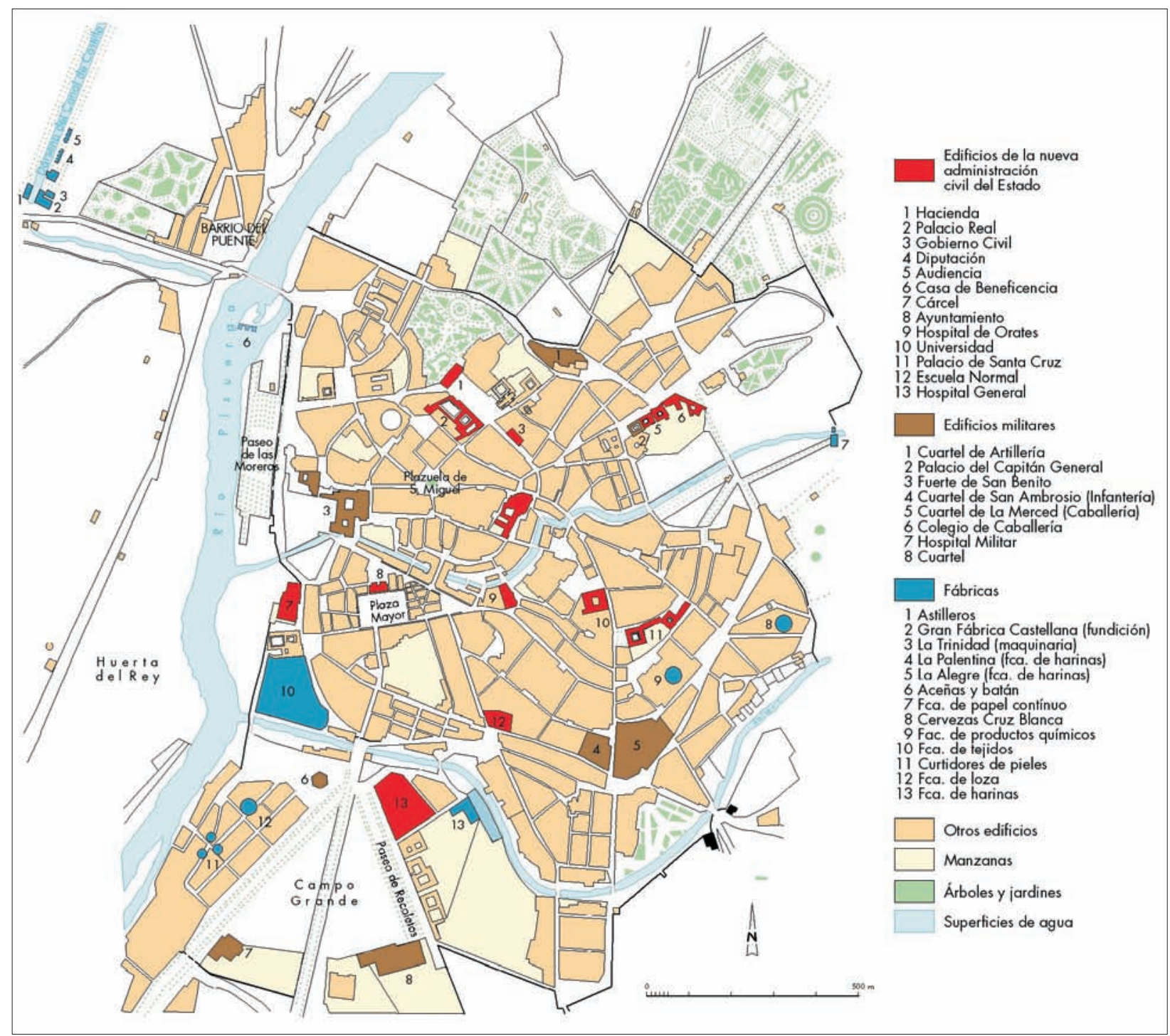

FIG. 8. Valladolid 1852. Primeros vestigios de la nueva sociedad industrial y burguesa. Fuente: elaboración propia a partir del plano de Valladolid de F. Coello (1852).

ron erigiéndose, por su valía arquitectónica y monumental, en iconos de la ciudad burguesa. Así ocurrió con los construidos para albergar el Banco de España, Correos, la Academia de Caballería (1852), la Delegación de Hacienda, el Hospital General, el Instituto o la Audiencia, trasladada más tarde a su sede actual de la corredera de San Pablo, a un edificio erigido sobre los solares que antes habían ocupado la casa de los López de Mendoza y el palacio de los Marqueses de Távara.

Los nuevos organismos también forjaron cambios funcionales significativos en todas las ciudades capitales, las cuales se consolidaron en poco tiempo como los principales centros administrativos de cada provincia (Fernández Cuesta, 2011, pp. 5-46). En Valladolid las nuevas funciones ya habían alcanzado un notable desarrollo en 1852, como puede descubrirse en el plano de Coello de ese año; ahora bien, adquirirían un peso aún mayor a lo largo de lo que quedaba de centuria, a medida que el desarrollo general del país promovía el crecimiento de la administración y el de los cuerpos de funcionarios, que terminó por convertirse en una fuente fundamental de riqueza. 


\section{B) La industrialización}

La economía de Valladolid en 1840 todavía presentaba síntomas inequívocos de su vinculación con el Antiguo Régimen. Su población activa ascendía a 5.721 personas, de las cuales el $21 \%$ trabajaban en el sector primario y el $23 \%$ en el servicio doméstico. Además, del $25 \%$ ocupado en el secundario la mitad aproximadamente producía textiles y pieles utilizando para ello técnicas todavía artesanales (Rueda Hernanz y Carasa Soto, 1983, pp. 237-251). Ahora bien, esta situación comenzó a cambiar muy rápidamente con la llegada de las primeras manifestaciones industriales.

La privilegiada situación de Valladolid en el centro geográfico de la cuenca del Duero fue sin duda un factor determinante para que acogiera, durante las décadas centrales del siglo XIX, dos importantes infraestructuras de transporte: la dársena del canal de Castilla, concluida en 1835 (Iglesias Rouco, 1978, p. 21) y la estación ferroviaria de Campo Grande, en torno a las cuales aparecieron los primeros focos fabriles de la ciudad.

En la dársena fluvial terminaba uno de los tres ramales del canal de Castilla (Sáez Hidalgo, 1994, p. 117) que discurría por la margen derecha del Pisuerga. Se construyó al noroeste de la ciudad, al otro lado del río, sobre el camino que se dirigía a Medina de Rioseco, y su importancia fue tal que García Fernández (1974, p. 20), uno de sus más conocidos estudiosos, considera el año de su inauguración (1842) como el del inicio del primer impulso industrializador, que llegaría hasta 1857. Muy cerca de ella, sobre el solar del antiguo convento de San Bartolomé, se construyó la estación del ferrocarril de vía estrecha que se dirigía a Medina de Rioseco, el primero de los vallisoletanos (1844) (Almuiña Fernández, 1985, pp. 17-240; Jiménez García, 1992, pp. 43-44), que ayudó a que este moderno espacio de transporte se convirtiera de inmediato en el principal centro de atracción fabril de la ciudad.

Pese a todo, la primera instalación fabril no se instaló en esta zona, sino en la margen izquierda del Pisuerga, a orillas del Esgueva. Se trataba de una fábrica de papel continuo inaugurada en 1842 por José Garraizábal que contaba con más de cincuenta trabajadores (Quirós Linares, 1991, p. 26). La instalación disponía de dos ruedas hidráulicas para obtener la energía mecánica con la que movía su maquinaria, pero contaba también con una máquina de vapor que funcionaba durante el verano, cuando la escasez de agua ponía en peligro el proceso de producción (Manual histórico y descriptivo de Valladolid, pp. 299-300).

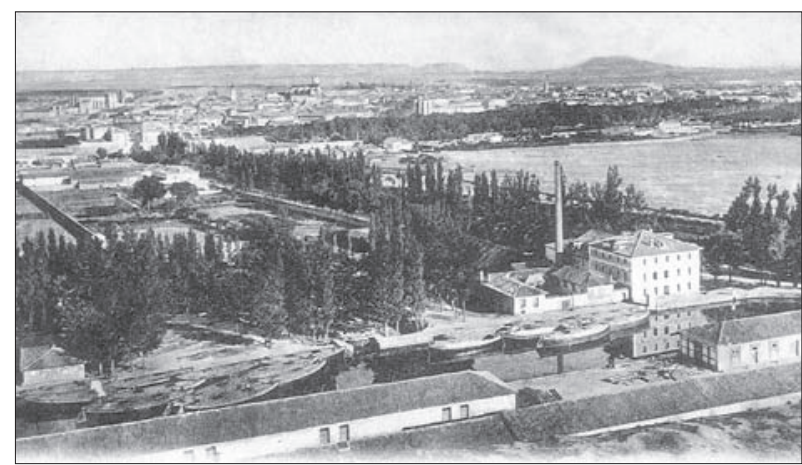

FIG. 9. La inauguración de la dársena del canal de Castilla en 1842 , sobre la margen derecha del Pisuerga, supuso el inicio de la industrialización de la ciudad. En torno a ella se configuró su primer espacio fabril, en el que sobresalían las fábricas de harina y las metalúrgicas.

Ahora bien, como decíamos, la mayor concentración de nuevos ingenios mecánicos tuvo lugar en las cercanías de la dársena. Antes de 1861 en su entorno se encontraban en funcionamiento unos astilleros, cuatro fábricas de harina (La Palentina, La Alegre, La Providencia y La Perla) y, sobre todo, una importante fundición, la Gran Fábrica Castellana, que disponía de una máquina de vapor y de una turbina, producía calderería y maquinaría, y empleaba a unas doscientas personas (Manual histórico y descriptivo de Valladolid, p. 300; García Fernández, 1974).

Al margen de estas instalaciones, otras muchas se habían repartido por otros lugares, y en 1848 los establecimientos catalogados como industriales eran 53. En el barrio de San Ildefonso, lindando con el Pisuerga, donde se concentraban las tenerías, se levantó una nueva fábrica de loza; y en el antiguo convento de La Trinidad una de maquinaria (La Trinidad) (Manual histórico y descrip-

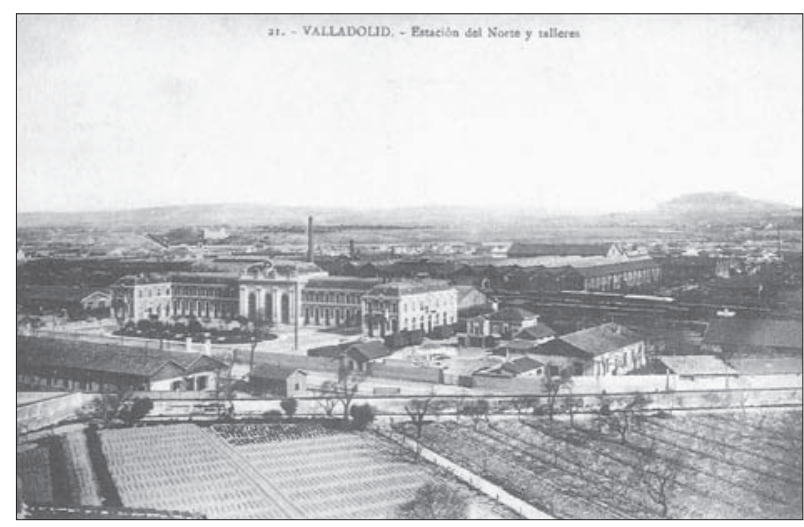

FIg. 10. La estación de Campo Grande, de los Ferrocarriles del Norte, ocupó el solar del antiguo convento de la Merced Descalza, y albergó, entre otras instalaciones, los talleres generales de la compañía. 


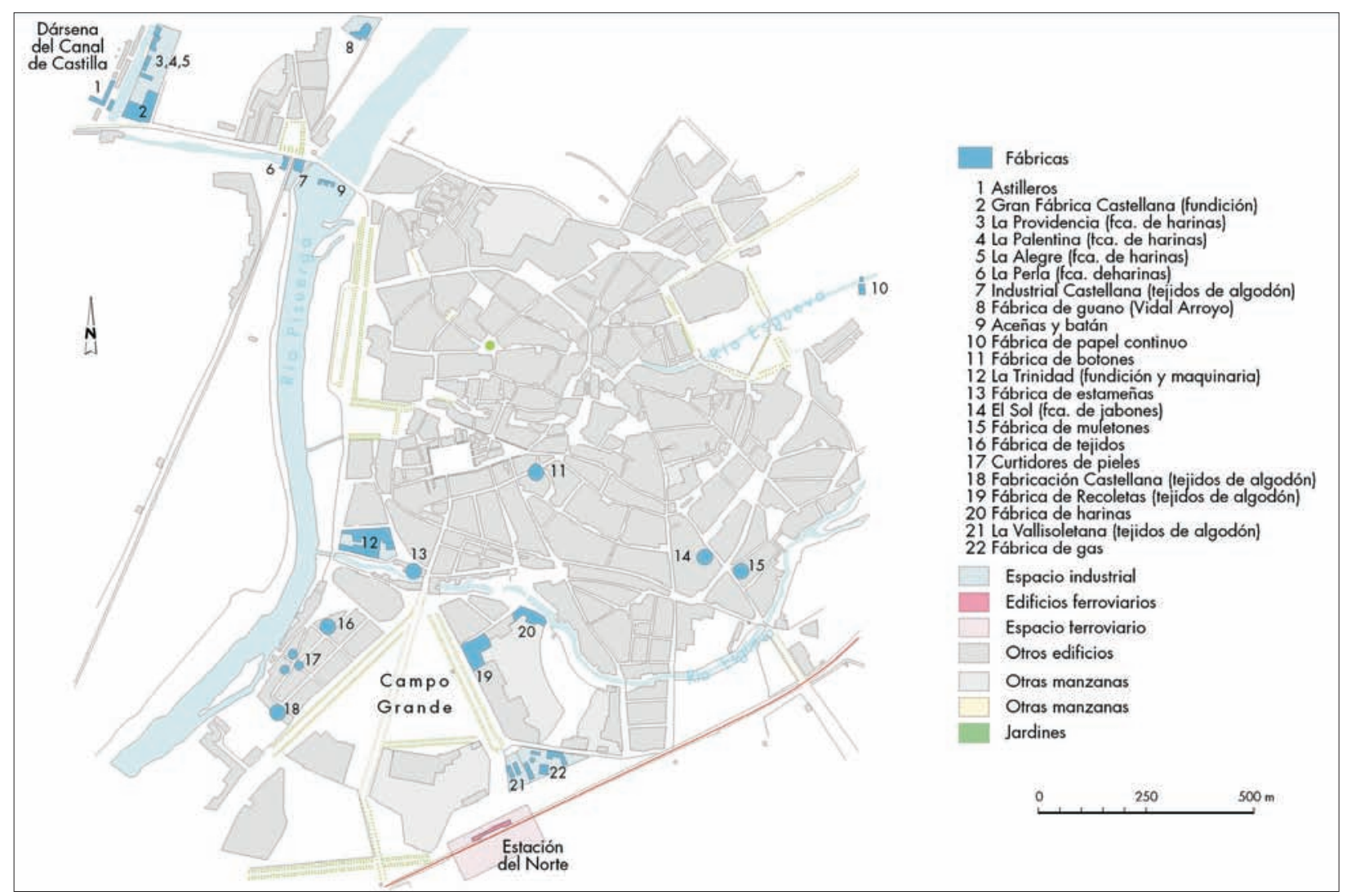

FIG. 11. El espacio industrial en Valladolid en 1863. Fuente: elaboración propia. La base cartográfica corresponde al plano de Valladolid de Pérez Rozas de 1863.

tivo de Valladolid, pp. 300-301); además, también habían abierto sus puertas otras plantas de abonos (García Fernández, 1974, pp. 18-20; Quirós Linares, 1991, pp. 17-42), de gas (Tortella, 1994, p. 188), de jabón, de botones, de estameñas y de muletones; $y$, por supuesto, seis establecimientos textiles, cuatro de los cuales utilizaban como materia prima el algodón (Moreno Lázaro, 2003, pp. 173-196). Entre estos últimos destacaba la firma La Vallisoletana, de Vidal, Semprún y Cía., que llegó a contar con 450 trabajadores (Manero, 1983, p. 30), pero también la Fabricación Castellana, La Recoletos o la Industria Castellana. Todas ellas contaban también con moderna maquinaria, utilizaban la fuerza del vapor y realizaban labores de tisura y tejido (Manual histórico y descriptivo de Valladolid, pp. 302-303).

A principios de la década de 1860 la ciudad inició una nueva etapa industrial favorecida por los intereses de la Compañía de los Caminos de Hierro del Norte de España. Esta sociedad, concesionaria de las líneas ferroviarias que tendrían que unir Madrid con Irún y con San- tander (F. Wais, 1974, pp. 237-244), eligió a Valladolid, entonces uno de los principales mercados nacionales de granos, para albergar algunas de sus más importantes instalaciones. El 1860, concluido el tramo de la línea principal que discurría entre la propia ciudad y Burgos, inauguró la estación de Campo Grande (F. Comín Comín, P. Martín Aceña, M. Muñoz Rubio y J. Vidal Olivares, 1998 , t. 1, pp. 67-70), que fue convertida en 1864, una vez finalizados todos los tramos de la línea Madrid-Irún, en el principal centro de redistribución de mercancías y en sede de sus oficinas generales (M. Jiménez García, 1992, pp. 41-42).

Dos años más tarde una nueva decisión reforzó la posición de privilegio que ya tenía la estación de Campo Grande en el engranaje de la Compañía del Norte: la de instalar en sus inmediaciones los talleres generales, con capacidad para arreglar y producir todo tipo de material ferroviario. Una vez concluidos aquéllos, el conjunto que formaba con la estación se convirtió en uno de los principales espacios ferroviarios españoles (Manero, 


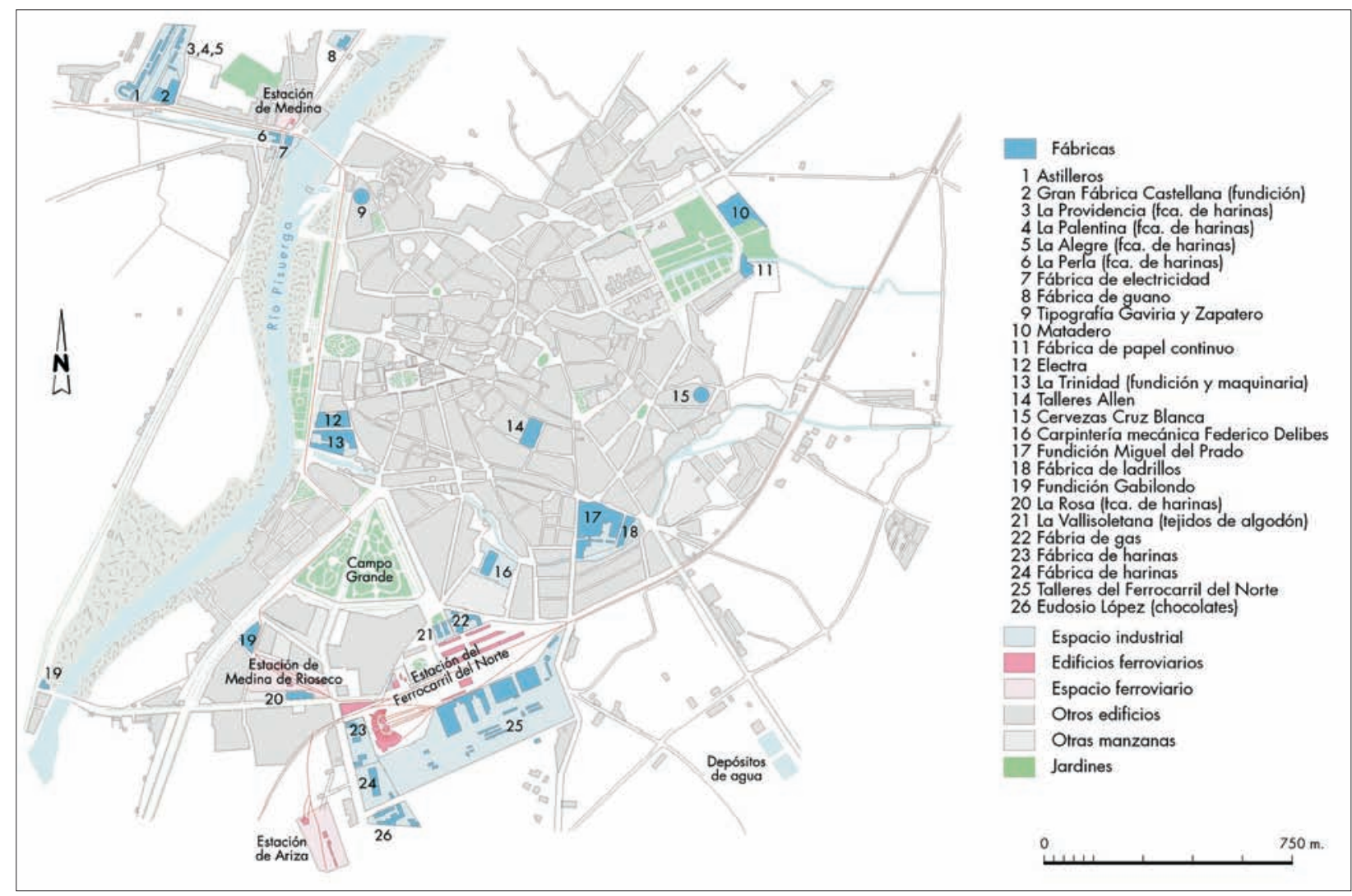

FIG. 12. El espacio industrial en Valladolid en 1896. Fuente: elaboración propia a partir plano de Valladolid de Montaner y Simón (1896).

1988, p. 16 ${ }^{21}$, al tiempo que comenzó a desempeñar una gran importancia económica y urbanística en la vida de la ciudad.

En poco tiempo, la nueva estación sustituyó a la dársena como principal foco de atracción de la actividad industrial y se convirtió en su primera fuente de empleo. A finales del siglo XIX, en este entorno, además de los talleres, en los que llegaron a trabajar más de tres mil personas (García Fernández, 1974, pp. 27-31), existían media docena de fundiciones, entre ellas las de Félix Aldea y Antonio Mihale (Díez Espinosa, 1985, p. 338), en el solar del antiguo convento de La Trinidad, o las de Gabilondo y Miguel del Prado. También se situaban muy cerca de la estación del ferrocarril tres nuevas harineras, la fábrica de gas, la de chocolate de Eudosio

\footnotetext{
${ }^{21}$ Este conjunto estaba formado no sólo por las instalaciones de la Compañía del Norte, además se encontraban en sus inmediaciones la nueva estación de Medina de Rioseco y la del ferrocarril Valladolid-Ariza, que unía la cuenca del Duero con el valle del Ebro, facilitando la salida de los granos castellanos hacia Barcelona y el litoral levantino.
}

López, La Vallisoletana, de lienzos de algodón, o la de herraduras y clavos de Ciriaco Sánchez, en la calle Doctrinos (Virgili Blanquet, 1985, pp. 467-467). Mientras, el otro espacio industrial, la dársena, mantenía su pujanza y albergaba una fundición, varias harineras, una fábrica de guano y otra de electricidad, la primera que funcionó en la ciudad.

Superada la crisis finisecular, Valladolid conoció un nuevo impulso durante las primeras décadas del siglo xx, y en 1934 ya disponía de un denso y variado tejido industrial que la convertía en uno de los principales focos fabriles periféricos de España (Manero, 1988, pp. 16-19). Durante esta época, el entorno de los talleres de la Compañía del Norte consolidó su posición y en 1934 sumaba, a las instalaciones existentes a principios de siglo, un buen número de fábricas modernas, que disponían de la nueva tecnología surgida de la segunda revolución industrial. Abrieron entonces sus puertas empresas eléctricas, de cerámica, metalúrgicas y alimentarias, entre las que destacaban, por su tamaño, la harinera El Palero, la Alcoholera, el Matadero Municipal, la Cerámica y, sobre 


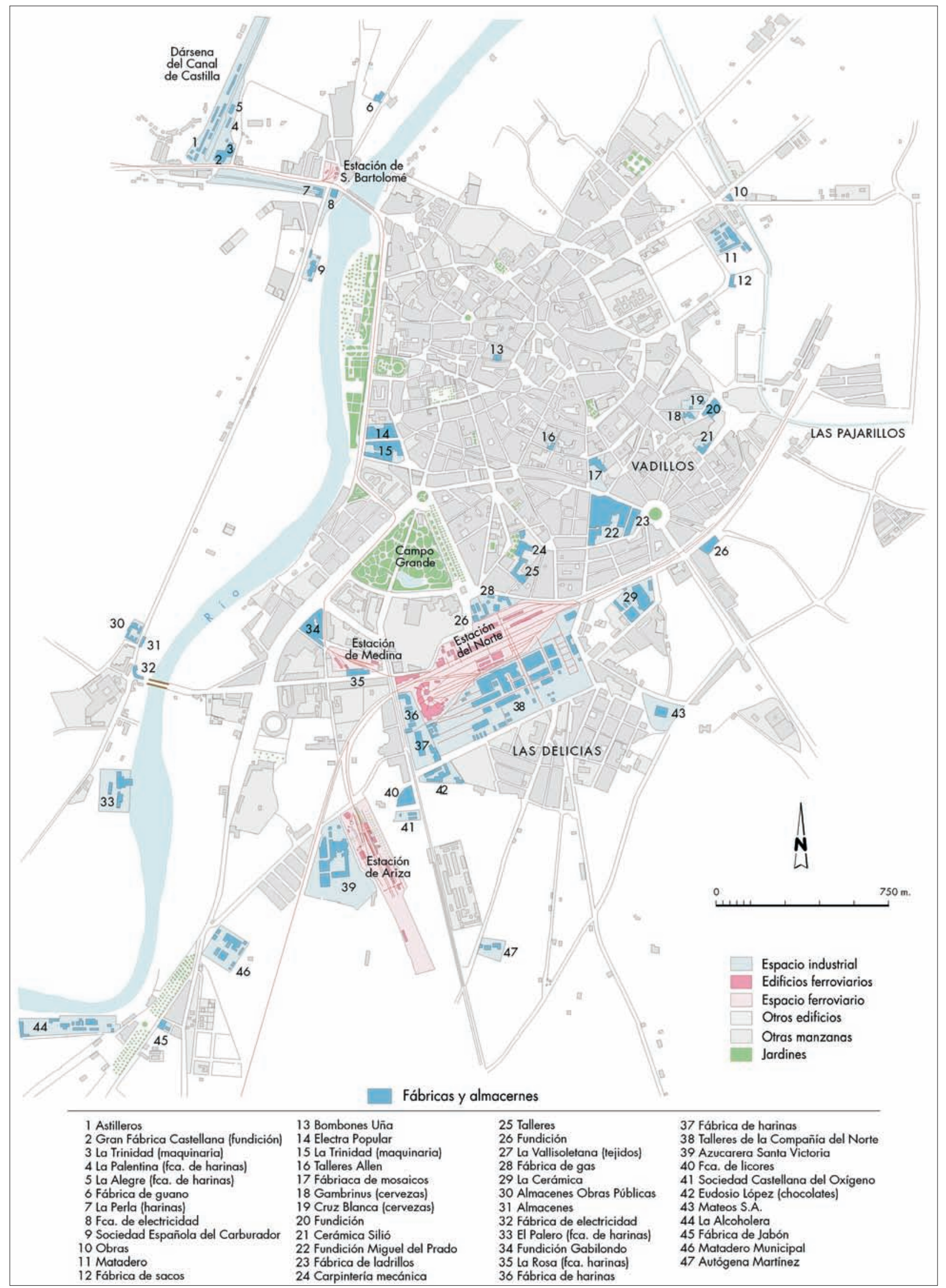

Fig. 13. El espacio industrial en Valladolid en 1934. Fuente: elaboración propia a partir del plano de Valladolid levantado por el Cuerpo de Estado Mayor del Ejército (1934). 
todo, la fábrica de azúcar de La Victoria, uno de los símbolos del momento, con sus instalaciones colindantes a la estación ferroviaria de La Esperanza.

Pero la industrialización no sólo fue el origen de los espacios industriales, también provocó la aparición de otra de las piezas fundamentales de la ciudad burguesa, los poblados obreros, que, sin embargo, no son objeto de estudio en este artículo. Ya a finales del siglo XIX comenzaron a surgir barrios de autoconstrucción, carentes del cualquier tipo de equipamiento, situados primordialmente a mediodía, en posición periférica, inaccesibles al núcleo tradicional (Palomares Ibáñez, 1981, pp. 16-19) y siempre muy cerca de las principales concentraciones industriales. Éste fue el origen de los barrios surgidos al otro lado de la línea ferroviaria, que formaban entre sí una aureola paralela a las vías, entre los que se encontraban La Pilarica, Los Pajarillos (Alto y Bajo) (Begines Ramírez, 1973), La Farola, Los Vadillos y Las Delicias; este último, el mayor de todos ellos, fue de origen ferroviario, lo que explica que se desarrollara en las inmediaciones de los talleres de la Compañía del Norte (Jiménez García, 1992, pp. 89-103).

\section{ORIGEN Y OCUPACIÓN DE LOS BALDÍOS EXISTENTES A MEDIADOS DEL SIGLO XIX}

Durante la fase culminante de la construcción de la ciudad burguesa, Valladolid pudo absorber la mayor parte del crecimiento de su población expandiéndose a un ritmo mucho menor del que experimentaba su población, pues pudo crecer hacia el interior de ella misma. Como ya hemos dicho, la ciudad disponía, en el interior de su antiguo recinto intramuros, de una gran cantidad de baldíos que una vez transformados en solares o en espacio urbanizable fueron suficientes para absorber una buena parte de la demanda de suelo provocada por el crecimiento demográfico.

El origen de los baldíos vallisoletanos, como el de otras ciudades de características similares (Sevilla o Granada), tenía una de sus causas en la desproporción existente entre el tamaño de su casco urbano y el de su población. Heredero aquél de una época anterior de mayor esplendor, tenía unas dimensiones exageradas para la población que albergaba en 1840. En su interior la densidad era tan sólo de 130 habitantes por kilómetro cuadrado, muy inferior a la de casi todas las principales ciudades españolas de la época. Densidades similares, si bien casi siempre superiores, sólo las tenían otros núcleos que también habían pasado por tiempos mejores en épocas precedentes, como Jerez de la Frontera, Segovia o Córdoba, por poner sólo ejemplos representativos.

Una segunda causa a tener en cuenta para comprender la extensión de los baldíos era la función eclesiástica que la ciudad había desarrollado, prácticamente sin interrupción, desde sus orígenes hasta finales del Antiguo Régimen. Función que quedaba reflejada sobre el espacio urbano a través de los numerosos edificios y solares, algunos de grandes dimensiones, que todavía eran propiedad de las instituciones religiosas, tanto regulares como seculares. En conjunto estas propiedades acaparaban una porción sustancial de la superficie urbana, la mayor parte de la cual quedó vacante después de que la desamortización eclesiástica, o de Mendizábal, las sacara a subasta para convertirlas en una mercancía más, factible, por tanto, de ser vendida o comprada.

La última de las causas que explicaba la amplitud del espacio disponible en el recinto intramuros era el tamaño de los cauces de las dos Esguevas que lo atravesaban, que ocupaban unas 85 hectáreas ${ }^{22}$. Una superficie cuya trascendencia futura es fácil de comprender si pensamos que superaba que equivalía a algo más de una cuarta parte de la que tenía la ciudad entonces, y, sobre todo, si la comparamos con la que tenían ciudades como Oviedo, Bilbao o Las Palmas, que no llegaban a ochenta hectáreas.

A mediados del siglo XIX el conjunto de estos baldíos alcanzaba unas proporciones enormes, mayores probablemente que en cualquier otra ciudad histórica española; suficientes, en cualquier caso, para satisfacer las necesidades de suelo durante décadas. Pero previamente debían ser convertidos en solares y mercantilizarlos; sólo así podrían acoger nuevos edificios, plazas, calles o cualquier otro tipo de equipamiento. La conversión se logró finalmente con la desamortización eclesiástica y el cubrimiento de los cauces del Esgueva y, una vez realizada, la burguesía pudo disponer, dentro del casco histórico, del suelo necesario para construir su propio espacio vital y atender también otras necesidades. Eso explica que entre 1850 y 1950 la población de Valladolid pudiera crecer a un ritmo tres veces mayor que su superficie: mientras que la primera se multiplicó por 7,9, la segunda lo hizo por $2,6^{23}$.

La desamortización tuvo efectos muy rápidos, pues tras su aprobación (aunque, como ya hemos visto, algu-

\footnotetext{
${ }^{22}$ Se trata de un cálculo aproximado que incluye el espacio afectado por los proyectos de urbanización realizados para integrar en la trama urbana los antiguos cauces del Esgueva y los solares colindantes que se vieron afectados por dichos proyectos.

${ }^{23}$ Según hemos podido calcular, la extensión aproximada del casco urbano de Valladolid en 1950 era de 2.500 hectáreas.
} 


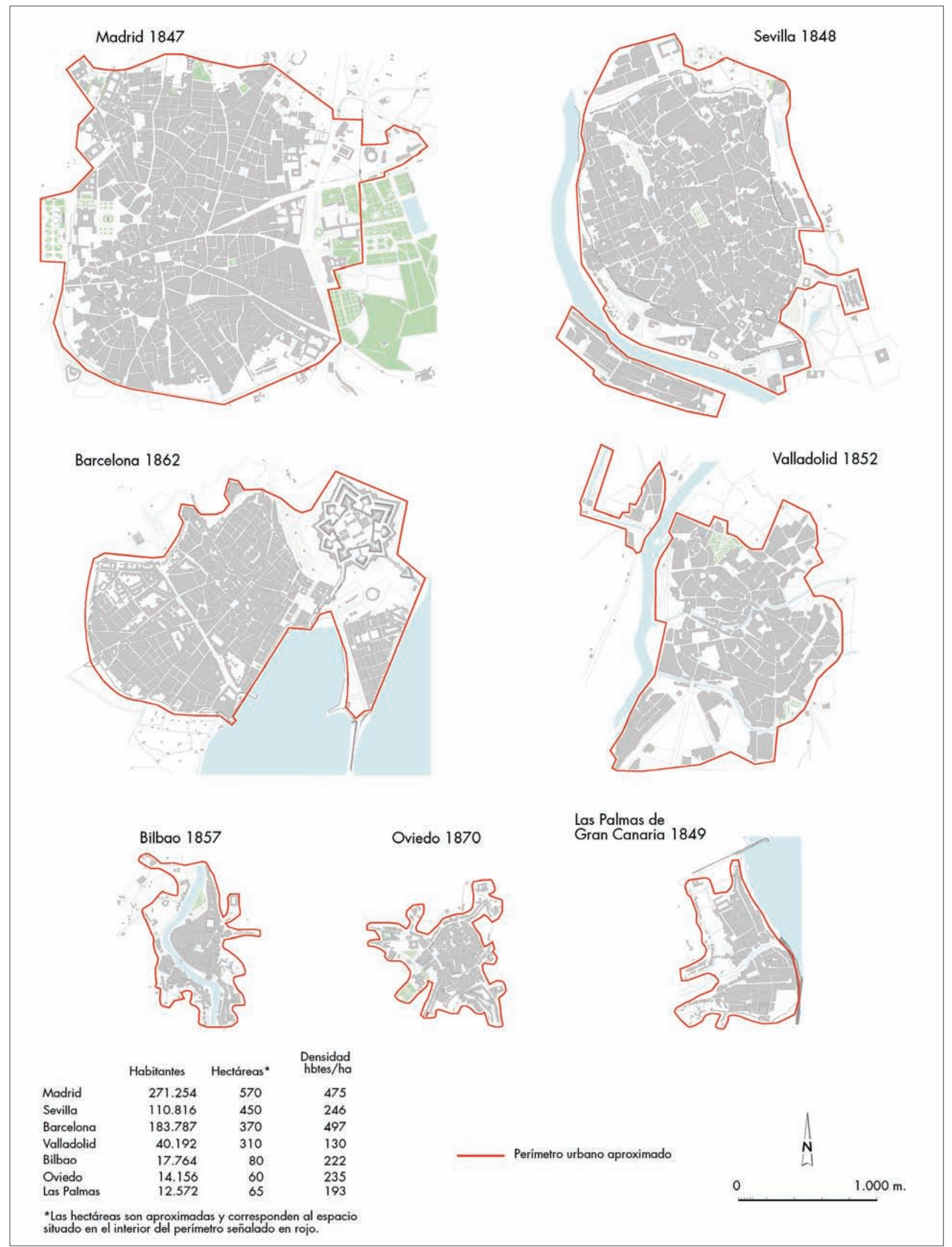

Fig. 14. El espacio urbano de Valladolid, en 1852, comparado con el de otras ciudades españolas. Fuente: los planos de Madrid, Barcelona, Valladolid, Bilbao, Oviedo y Las Palmas han sido dibujados a partir de los publicados por F. Coello (1847-1876); y el de Sevilla, a partir del realizado por D. José Herrera Dávila (1848). 


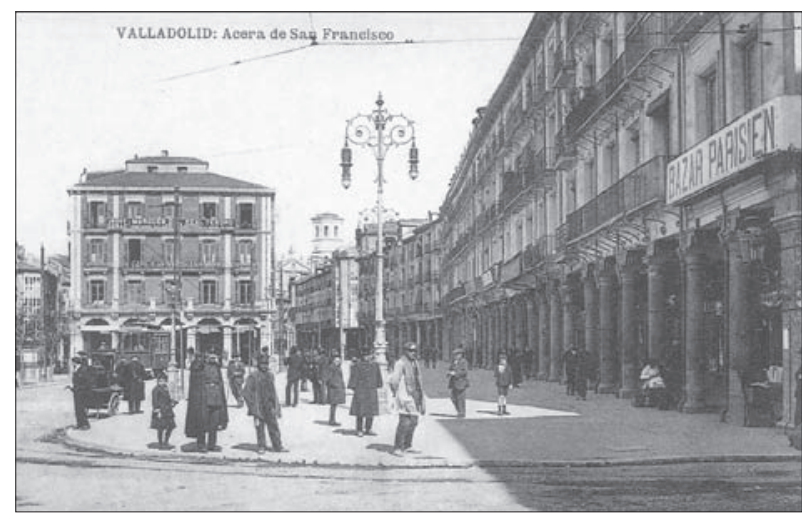

FIG. 15. La acera de San Francisco, en la plaza Mayor, recibe su nombre del antiguo convento que ocupó ese lugar hasta mediados del siglo XIX; uno de los mayores y más importantes de la ciudad.

nos se mantuvieron en pie y fueron reutilizados) muchos edificios fueron vendidos, demolidos y convertidos en solares que, al ser de propiedad privada, pronto fueron sacados al mercado para su posterior venta. Los conventos de San Francisco, Recoletos, el Corpus, Trinitarias, San Felipe, Franciscas y otros dejaron en el centro grandes solares vacíos que posteriormente fueron parcelados; y lo mismo ocurrió con otros más periféricos, como la Merced Descalza, Capuchinos, La Laura, Sancti-Spíritus, Nuestra Señora de la Soledad o San Bartolomé.

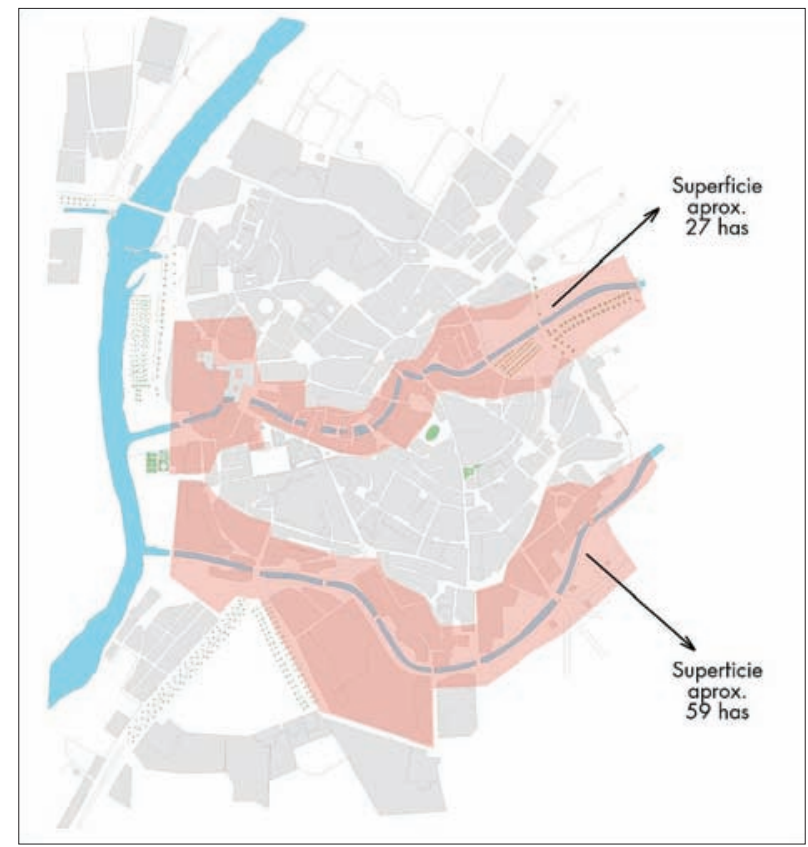

FIG. 16. Espacio aproximado afectado por los proyectos de ocupación del antiguo cauce de las Esguevas. Fuente: elaboración propia.

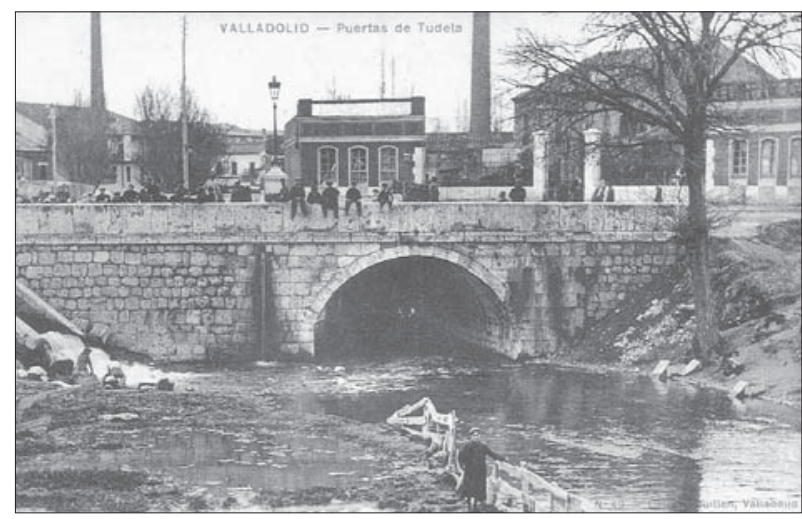

FIg. 17. Puente del Esgueva cerca de la antigua puerta de Tudela, en cuyas inmediaciones se instalaron varias fábricas, entre ellas la fundición de Miguel del Prado. Soterrado el cauce, el lugar fue ocupado por la plaza Circular.

Cubrir los cauces de los dos brazos del Esgueva fue una tarea más compleja y también más dilatada en el tiempo, a pesar de que era una vieja aspiración de los poderes públicos de la ciudad. Durante siglos la población había utilizado sus cauces como basurero y destino de sus desperdicios e inmundicias, habiendo llegado a colmatarlos, lo que suponía un riesgo en los casos de crecida del río, además de convertirlos en un foco permanente de infecciones y enfermedades (Calderón Calderón, 1991, pp. 35-42). Los peligros originados por esta situación se pusieron de manifiesto en 1788, después de que una gran riada arrasara buena parte de los edificios existentes entre el prado de la Magdalena y en el convento de San Benito. Si embargo, la escasez de los recursos municipales, insuficientes incluso para financiar la reconstrucción de los destrucciones ${ }^{24}$, convertía en quimera la simple idea del soterramiento.

La conciencia sobre la necesidad de mejorar la limpieza, el saneamiento y el ornato de la ciudad, alcanzó un nuevo impulso en las primeras décadas del siglo XIX. En 1820 el Ayuntamiento se propuso llevar a cabo una limpieza integral de los cauces de los ríos y en 1848, a raíz de una epidemia de cólera, comenzó a cubrirlos (Virgili Blanquet, 1985, pp. 468-471). Ahora bien, la falta de fondos y la complejidad del objetivo retrasaron la recuperación definitiva de los dos brazos del río durante varias

${ }^{24}$ Según Virgili Blanquet (1985, pp. 458-462), la inundación destruyó 76 casas y afectó a otras 54. Los daños fueron especialmente importantes en la calle Platerías, de manera que se aprovechó la circunstancia para reconstruirla y otorgarla la uniformidad arquitectónica que todavía hoy podemos contemplar. En este proyecto intervinieron los arquitectos José Santos Calderón y Francisco Álvarez Benavides. 

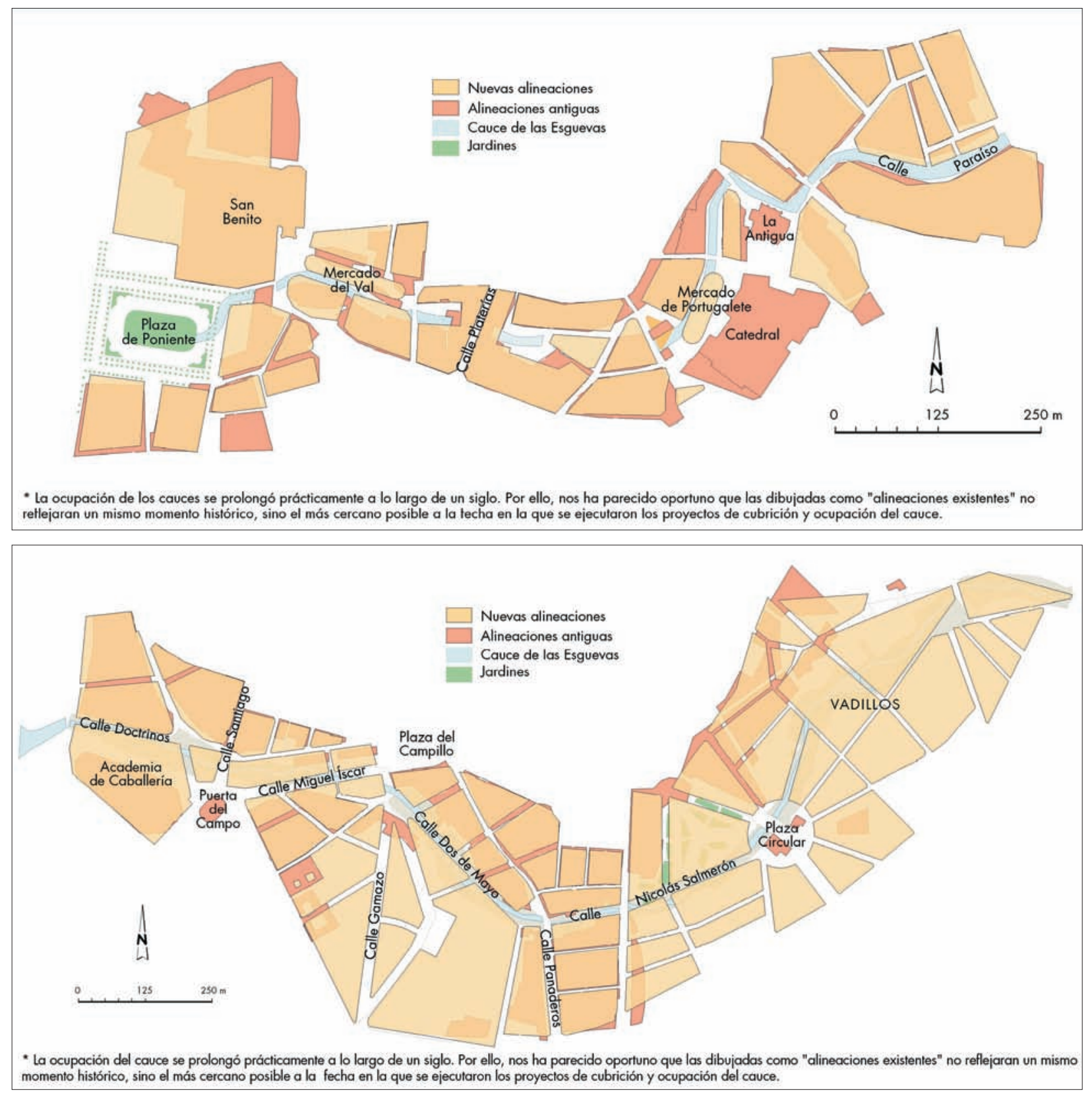

Figs. 18 y 19. La urbanización de los cauces septentrional (arriba) y meridional (abajo) del Esgueva, entre 1840 y 1930 aproximadamente. Las denominadas «alineaciones existentes» corresponden a las que perduraban en el momento en el que se ejecutaron los proyectos de soterramiento y ocupación del cauce. Fuente: Elaboración propia a partir de: Plano de Valladolid de F. Marrón (1839): Plano de Valladolid de F. Coello (1852); A. Álvarez Mora (2005); y E. Carazo Lefort (2010).

décadas, de manera que las obras solo concluyeron terminada la guerra civil, después de que fueran ejecutados los numerosos proyectos aprobados al respecto.

Según podemos comprobar en los diferentes planos realizados de la ciudad, durante la segunda mitad del siglo XIX, las obras se iniciaron en la Esgueva septentrio- nal. En el plano de Coello (1852) todavía no existe ningún tramo tapado, pero en el de 1863, de Pérez Rozas, ya aparece cubierto el tramo que discurría entre La Antigua y su desembocadura. Con posterioridad, las obras de encauzamiento continuaron hacia el este, y en 1863 se abrió también la calle Paraíso sobre la bóveda construida so- 
bre el río (Iglesias Rouco, 1978, p. 483; Virgili Blanquet, 1979 , p. 54); finalmente, las tareas pudieron darse por concluidas a finales de esa misma década con el soterramiento del río en el prado de la Magdalena, en donde se levantarían más tarde el hospital provincial y la Facultad de Medicina.

Una vez cubierto este cauce, los solares obtenidos fueron destinados primordialmente a equipamientos. Sobre la vaguada que se extendía entre la catedral y la iglesia de las Angustias se levantó el mercado de Portugalete y frente al pórtico de San Benito el del Val; ambos de morfología muy alargada, adaptada al antiguo cauce del río.

El encauzamiento de la Esgueva meridional fue más tardío. Comenzó cubriéndose el tramo que discurría entre la plaza del Campillo y la puerta del Campo, en el límite sur de la calle Santiago, conforme a lo recogido en el Plan de Mejoras, diseñado por el arquitecto Martín Saracíbar en 1863. Más tarde, las obras de soterramiento experimentaron un nuevo impulso con dos proyectos realizados por el arquitecto municipal, Ruiz Sierra. El primero, de 1879, lo planteó para cubrir el tramo comprendido entre la actual plaza de Zorrilla y el paseo del Espolón (Moreras) (Virgili Blanquet, 1985, p. 484), sobre el que se abriría la calle Doctrinos. El segundo, realizado en 1880 , tenía como objetivo parcelar la gran manzana situada entre la acera de Recoletos y la calle Panaderos, y entre sus propuestas estaba soterrar el Esgueva entre esta última calle y la plaza del Campillo para abrir sobre su bóveda una nueva vía (Virgili Blanquet, 1979,p. 56). Ahora bien, la ejecución de estos dos proyectos fue muy lenta y todavía no aparecen plenamente ejecutados en el plano publicado en 1911 por la España Regional ${ }^{25}$.

Más tardías aún fueron las obras de soterramiento en la parte oriental del cauce. El expediente para cubrir el río entre la calle Panaderos y la plaza Circular data de los primeros años de la década de 1910 y las obras de soterramiento parece que estaban concluidas en 1917; el mismo año en el que se iniciaron las gestiones para abrir sobre la bóveda la calle Nicolás Salmerón, cuya apertura se retrasaría hasta 1920 (Virgili Blanquet, 1979, p. 56). Por último, el tramo que discurría al este de la plaza Circular, por el paraje denominado de los Vadillos, se cubrió a partir de varios proyectos diferentes aprobados partir de 1883. Las obras de ejecución de los mismos se iniciaron con posterioridad a 1920 (Virgili Blanquet, 1979,

\footnotetext{
${ }^{25}$ En dicho plano la calle Doctrinos sólo está abierta en su vertiente norte, la sur todavía está ocupada por la aguas del río.
}

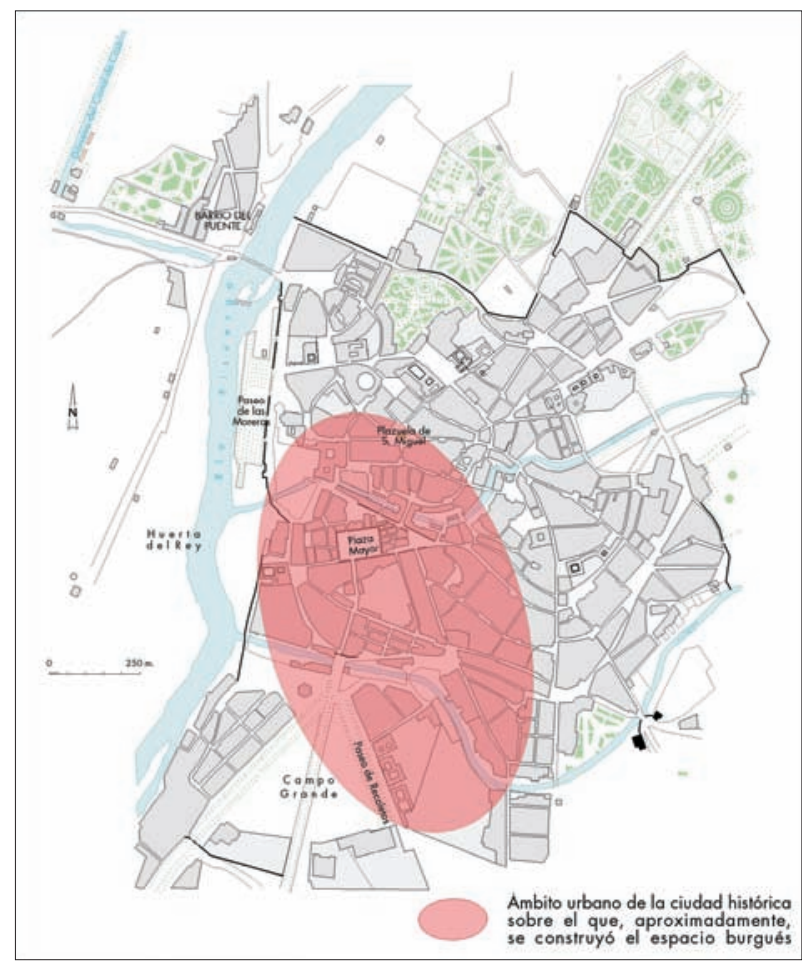

FIG. 20. Valladolid, 1852. Extensión aproximada del ámbito urbano sobre el que se construyó el espacio burgués. Fuente: elaboración propia sobre la base del plano de Valladolid F. Coello (1852).

pp. 71-72), pero, según se desprende del plano realizado por el Cuerpo del Estado Mayor del Ejército en 1934, ya estaban muy avanzadas en ese año.

\section{LA CONSTRUCCIÓN DEL ESPACIO BURGUÉS}

Entre 1850 y 1930, Valladolid, como consecuencia de la ausencia de propuestas de ensanche, no dispuso de ningún plan urbanístico que diseñara globalmente el espacio adaptado a las necesidades de la burguesía. La formación de éste se debe a la suma de las tramas que resultaron de la ejecución de muchos pequeños planes de reforma interior $^{26}$, muy dispares entre sí y no siempre cumplidos en su integridad. Estas circunstancias dificultan el seguimiento del proceso que dio origen al espacio burgués, y también

\footnotetext{
${ }^{26}$ En ausencia de un plan unitario, el diseño definitivo de este espacio se debe a los distintos arquitectos que firmaron los numerosos proyectos de alineación aprobados para esta zona, pero también a la acción de los propietarios del suelo que se interpusieron muchas veces en defensa exclusiva de sus propios intereses (Carazo Lefort, 2010; Álvarez Mora, 2005, pp. 102-103).
} 


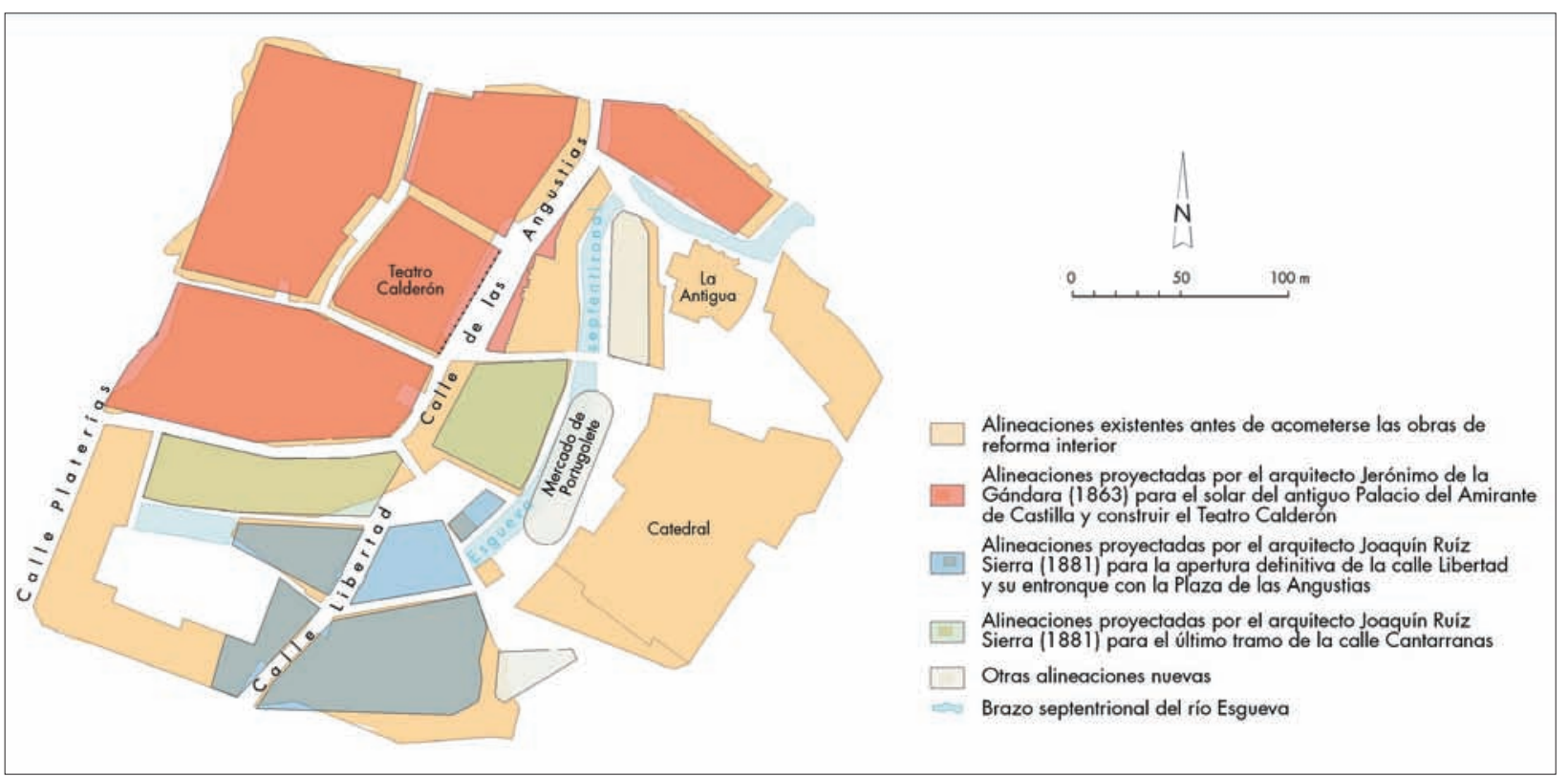

FIG. 21. Proyectos de reforma interior que diseñaron el trazado actual de la plaza de las Angustias (1863) y de la calle Libertad (1881). Fuente: elaboración propia a partir de diferentes planos que aparecen en Carazo Lefort (2010).

la comprensión de su entramado, pues se mezclan en él elementos modernos, derivados del planeamiento, con otros antiguos, vestigios de la trama del Antiguo Régimen sobre la que se construyó.

Pero, pese a esta complejidad, una vez concluida la reforma interior, Valladolid disponía de un espacio construido por y para la burguesía, situado intramuros de la ciudad histórica, que tenía una fisonomía sorprendentemente similar a la de los ensanches de otras ciudades. Un espacio que, no por causalidad, ocupó la parte meridional de la ciudad, al sur de la plaza Mayor, que hasta ese momento había sido su más importante centro económico.

En esta zona proliferaban los conventos, con grandes solares de baja edificación que quedaron vacantes después de la desamortización; fue el lugar elegido por la Compañía del Norte para construir su estación, que se convirtió desde su inauguración en la nueva puerta de acceso a la ciudad; por ella discurrían los dos brazos del Esgueva que, una vez cubiertos, se transformaron en solares factibles de ser utilizados para nuevos usos; y, por último, allí se encontraba el Campo Grande, un ámbito muy adecuado para el disfrute y lucimiento de la burguesía (Carazo Lefort, 2010, p. 45).

Los múltiples proyectos aprobados por el Ayuntamiento con el fin de construir este espacio, dotarlo de equipamientos y adaptarlo a los modernos medios de transporte y a las necesidades comerciales pueden cla- sificarse en tres grupos en virtud del momento en el que fueron aprobados y del objetivo con el que fueron concebidos:

- los sancionados para «modernizar» la trama urbana entre los dos brazos del Esgueva;

- los aprobados para urbanizar la gran manzana situada entre el Campo Grande y la calle Panaderos.

- las realizados, ya entrado el siglo xx, para dar forma definitiva al espacio burgués.

\section{A) La reforma interior entre los dos brazos del Esgueva}

Por el norte, el espacio burgués casi nunca sobrepasó la línea marcada por el antiguo brazo septentrional del Esgueva, quedando fuera del mismo el antiguo recinto en el que se concentraban la mayoría de los palacios y edificios monumentales de la ciudad, muy deteriorado durante la larga etapa de agonía que se inició con la salida de la Corte.

Por encima del brazo septentrional los pocos planes que dejaron huella en la ciudad burguesa se concentraron cerca del antiguo cauce. Para reorganizar el espacio situado al este de la plaza Mayor, entre la calle Platerías y la catedral, se presentaron varios proyectos. El de más envergadura, y también el más antiguo, lo diseñó el arquitecto Jerónimo de Granda en 1863 para urbanizar el 


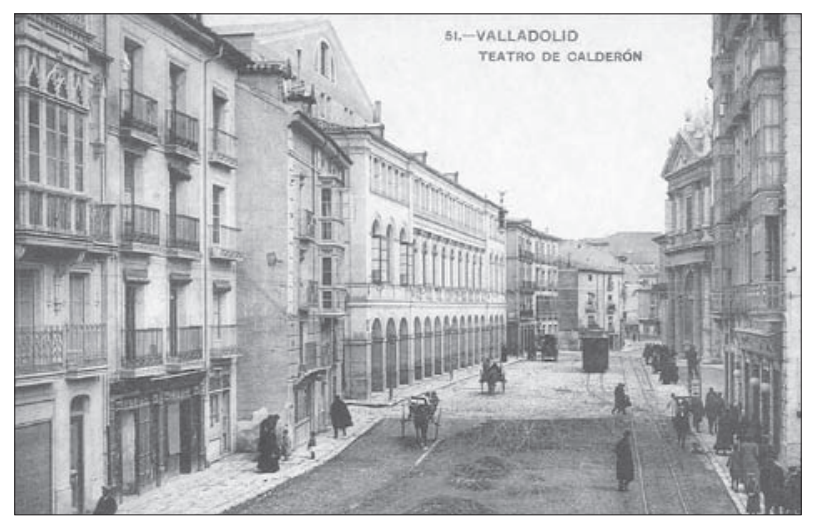

Fig. 22. El Teatro Calderón, en la plazuela de las Angustias, símbolo de la burguesía emergente, fue construido sobre el solar que había ocupado el palacio del Almirante, derribado en 1863.

solar que había ocupado el palacio del Almirante, uno de los mayores de la ciudad, que había sido derribado ese mismo año por la sociedad promotora a la que pertenecía entonces. Granda dividió el solar en dos manzanas separadas por la actual calle de Alonso Berruguete, una de las cuales acogería el Teatro Calderón, símbolo indiscutible del poder y de los ideales sociales de la burguesía. Las alineaciones más orientales de este proyecto, junto con las que surgieron de los aprobados para rectificar el último tramo de la calle Cantarranas y abrir la calle Libertad, ambos del arquitecto Ruiz Sierra (1881), también sirvieron para alinear y ensanchar la calle Angustias, al tiempo que para enlazar el tramo final de ésta con la plaza de Fuente Dorada.

Sobre el propio cauce del Esgueva, el proyecto más destacado fue, tal vez, el que realizó el arquitecto municipal Martín Saracíbar (1863) para ocupar la explanada de San Benito, surgida de la canalización del último tramo del río, antes de su desembocadura en el Pisuerga. Sobre la explanada el arquitecto diseñó la plaza de Poniente, un nuevo espacio verde en el corazón del casco histórico que debería de servir de nexo de unión entre éste y el paseo de las Moreras; pero el proyecto también incluía las nuevas alineaciones que deberían delimitar el perímetro exterior de la plaza y el de sus manzanas colindantes.

Ahora bien, donde comenzó a gestarse el ámbito residencial de más prestigio fue entre los dos brazos del Esgueva, que más tarde se prolongó hacia el sur en un claro intento de acercarse al ferrocarril. En esta parte de la ciudad el proceso de transformación de la trama urbana comenzó en 1847 con la parcelación del solar que ocupaba el desamortizado convento de San Francisco, cuyos dominios se extendían entre la plaza Mayor y la calle Montero Calvo. En dicho solar se proyectaron tres manzanas que

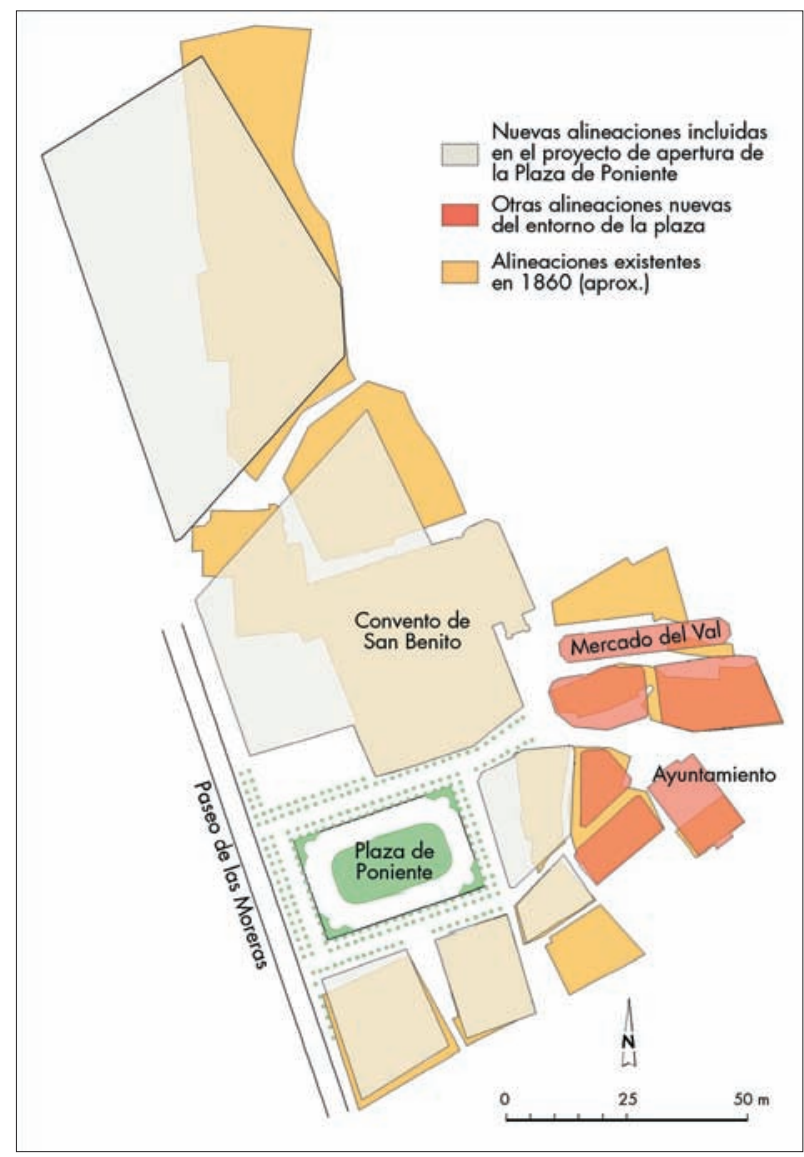

FIg. 23. Proyecto de alineación de la explanada de San Benito, del arquitecto Martín Saracíbar (1863). Fuente: elaboración propia a partir del plano que aparece en Carazo Lefort (2010).

dieron origen a las calles Mendizábal y Constitución, esta última abierta entre las de Santiago y Olleros (Duque de la Victoria) y pronto convertida en una de los principales vías burguesas (Álvarez Mora, 2005, p. 96).

Una vez abierta, la primera de ellas contó pronto con un proyecto de prolongación que pretendía convertirla en una gran vial que discurriese al sur de la plaza Mayor, en el sentido de los paralelos, entre la calle María de Molina y la plaza de Orates. El proyecto fue firmado por el arquitecto Martínez de Velasco en 1861 (Álvarez Mora, 2005 , p. 98), pero su ejecución se prolongó durante casi treinta años debido a su complejidad, ya que su viabilidad entrañaba la ruptura de varias manzanas de la trama histórica. Las obras de prolongación se iniciaron hacia el este, siendo el primer tramo inaugurado el que llegaba hasta Teresa Gil (1878), denominado Alfonso XII. En el mismo año se terminaron las obras de apertura hasta la calle Sierpes y en 1891, por fin, la nueva calle alcanzaba la plaza 


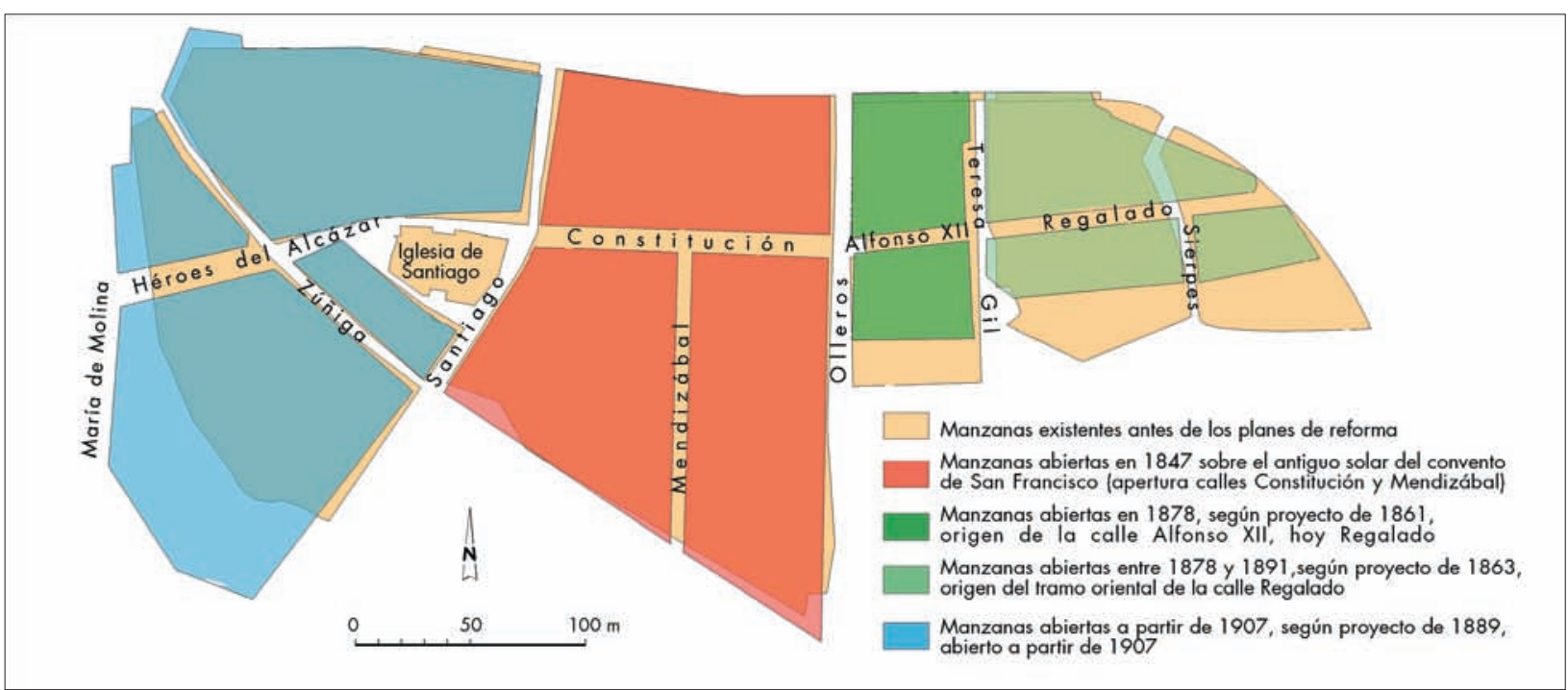

FIG. 24. Proyecto de apertura de la calle Constitución (1861), del arquitecto Martínez de Velasco, y sus prolongaciones hacia el este y el oeste. Fuente: elaboración propia a partir del plano que recoge Álvarez Mora (2005) y la información que aparece en Virgili Blanquet (1979)

de Orates. En el otro sentido, las obras de prolongación hasta María de Molina comenzaron más tarde, pues antes fue preciso modificar varias veces el proyecto original para salvaguardar la iglesia de Santiago. El definitivo se aprobó en 1889 y su ejecución concluyó en 1907, una vez abierto el último tramo de la calle Héroes del Alcázar, y trazada la nueva alineación de la calle Zúñiga.

Estas primeras transformaciones de la trama urbana, incluso las que aún no estaban concluidas, ya aparecen recogidas en el primer plano métrico de Valladolid de 1863. Un plano encargado por la corporación municipal a Pérez de las Rozas para que sirviera de base a los futuros proyectos de alineaciones que ella misma pudiera encargar.

La modernización de la trama al sur del eje formado por la calle Constitución y sus prolongaciones se completó con varios proyectos diferentes, pero uno destaca por encima de todos los demás, el realizado en 1863 por el arquitecto municipal Martín Saracíbar. El Plano de la parte de mediodía de la ciudad de Valladolid con los proyectos de mejoras ${ }^{27}$ preveía la rectificación, ensanchamiento y alineación de la mayoría de las antiguas calles de la zona ${ }^{28}$, entre ellas la acera oriental de Olleros ${ }^{29}$, con-

${ }^{27}$ Véase Carazo Lefort (2010, p. 50, n. 52), donde se aclara la autoría del proyecto, otorgándosela a Martín Saracíbar (AmVA c 976-20, 1863-1864).

${ }^{28}$ Incluía la alineación de las calles Teresa Gil, San Felipe, Santiago, Panaderos, Labradores, Orates y Sierpes (Virgili Blanquet, 1979, p. 60).

${ }^{29}$ La margen occidental había quedado prácticamente terminada con la parcelación del solar del antiguo convento de San Francisco.

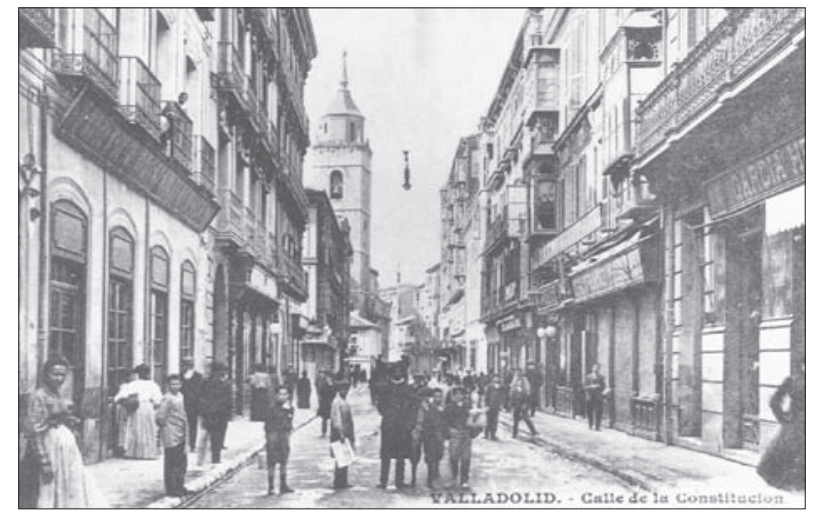

FIG. 25. La calle Constitución, abierta en 1847 sobre el solar que había ocupado el convento de San Francisco, fue una de las primeras arterias burguesas de la ciudad. Más tarde fue prolongada hacia el este con la apertura de las calles Alfonso XII (hoy Regalado), Regalado y Cascajares.

vertida posteriormente en Duque de la Victoria, o la de Claudio Moyano.

También contemplaba sanear y cubrir uno de los tramos más contaminados del Esgueva, el que discurría por el Rastro, para posteriormente transformarlo en un gran bulevar. Fue éste el origen de la calle Miguel Íscar, trazada sobre la bóveda del río, cuyas obras se encontraban muy avanzadas en 1880 (Virgili Blanquet, 1979, pp. 5556) cuando recibió el nombre del recién fallecido alcalde de la ciudad, gran impulsor de su modernización. 


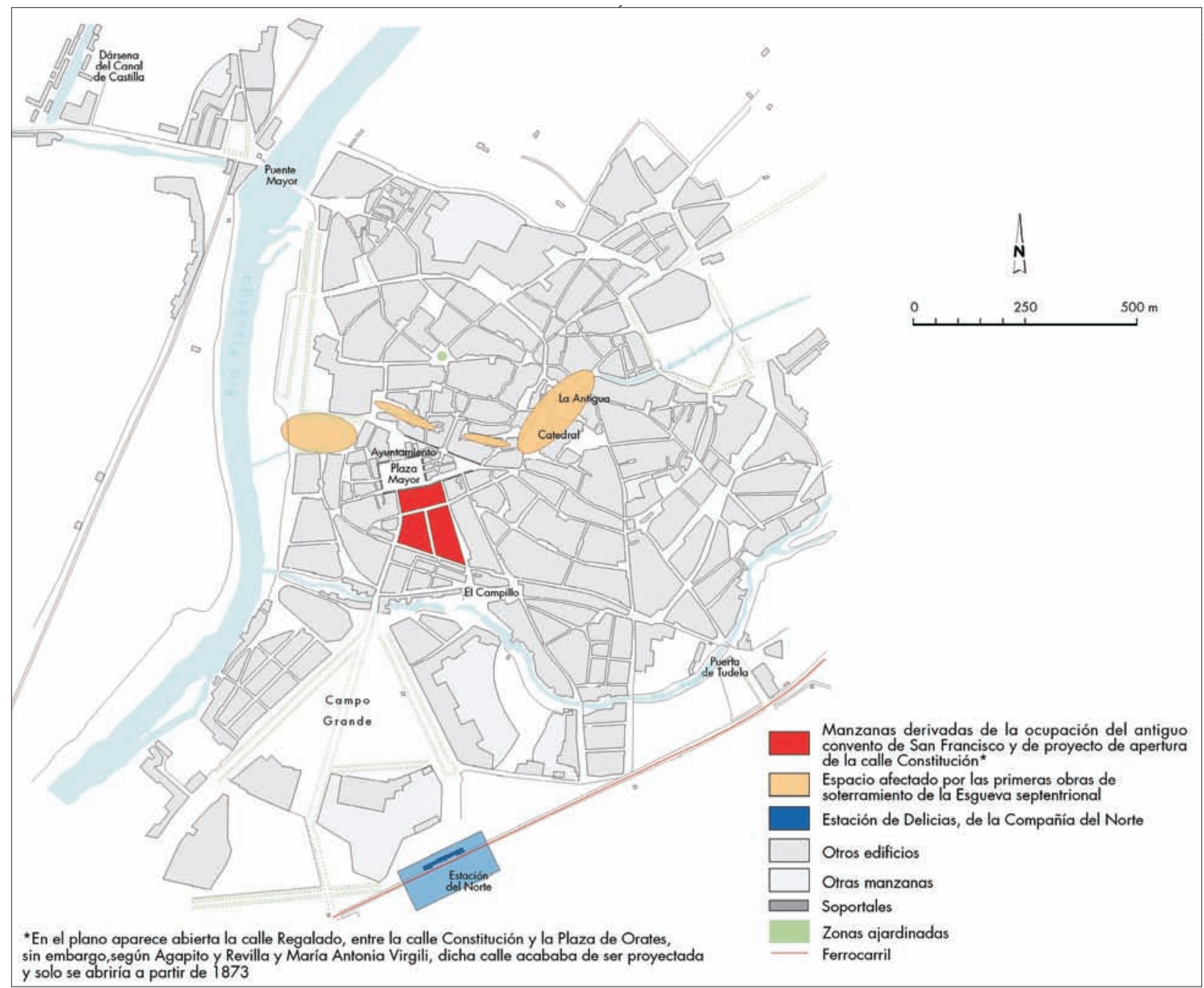

FIG. 26. Valladolid en 1863. Las primeras transformaciones urbanas. En el plano aparece abierta la calle Regalado, entre la calle Constitución y la plaza de Orates; sin embargo, según Agapito y Revilla y María Antonia Virgili, dicha calle acababa de ser proyectada y solo se abriría a partir de 1873. Fuente: elaboración propia. La base ha sido tomada del plano de Valladolid de J. Pérez de las Rozas (1863).

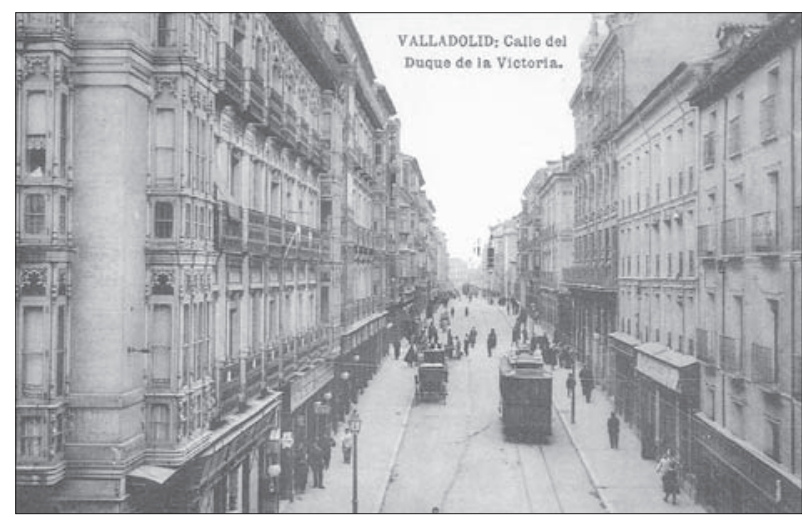

FIG. 27. La calle del Duque de la Victoria, antigua Olleros, se concibió desde sus orígenes como una gran arteria burguesa que debía servir también para facilitar la comunicación directa entre la plaza Mayor y la estación de Campo Grande.

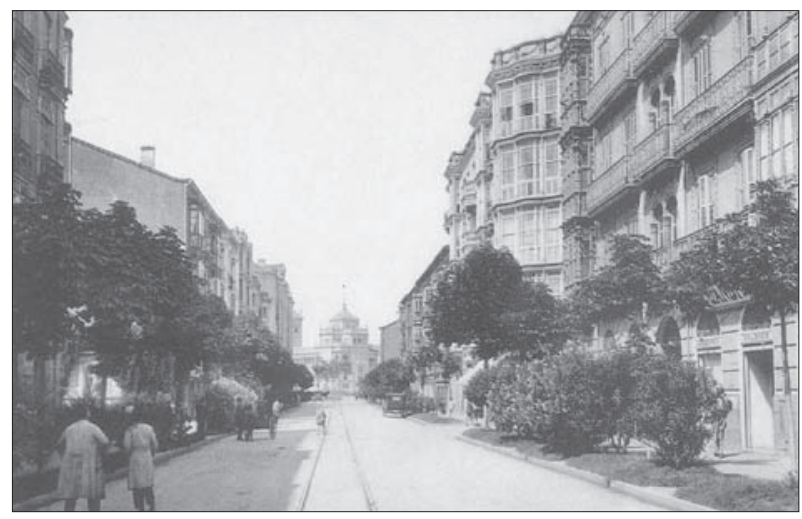

FIG. 28. La calle Miguel Íscar, abierta en 1880, aprovechó para su trazado la bóveda construida para soterrar el cauce del Esgueva entre la plaza del Campillo y la calle Santiago. Recibió su nombre en recuerdo del entonces recientemente fallecido alcalde de la ciudad. 


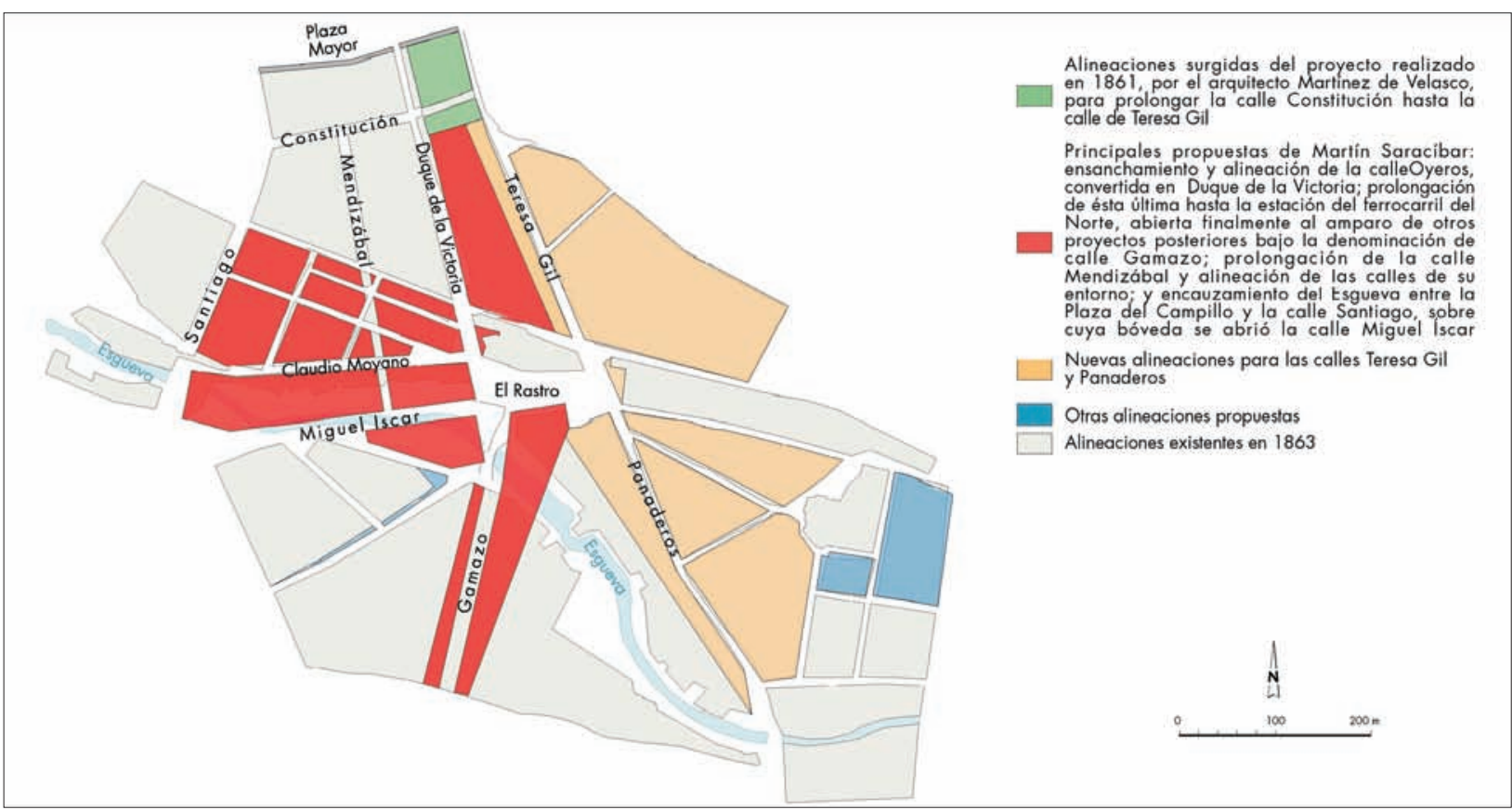

FIG. 29. Plano general de la parte del mediodía de la ciudad de Valladolid con los proyectos de mejoras diseñados por el arquitecto municipal Martín Saracíbar (1863). Fuente: elaboración propia a partir de los planos que aparecen en Virgili Blanquet (1979) y Álvarez Mora (2005).

Saracíbar también tiene el honor de haber incluido en su proyecto, por primera vez en la historia de la ciudad, el trazado de una calle para unir la plaza del Campillo con la estación a través de la gran manzana que se extendía entre el Campo Grande y la calle Panaderos. Aunque se trataba solo de un primer boceto, la idea fue retomada en un proyecto posterior para dar su alineación actual a la calle Gamazo.

\section{B) La parcelación de la gran manzana situada} entre el Campo Grande, el Rastro y la calle Panaderos

El ferrocarril constituyó desde sus orígenes un elemento destacado de la ciudad burguesa ${ }^{30}$. Las estaciones, construidas en origen en la periferia ${ }^{31}$, pronto se convir-

\footnotetext{
${ }^{30}$ La impronta del ferrocarril en la ciudad burguesa ha sido muy importante: «[...] su penetración [...] fue un hecho indiscutible; se introduce cuando todavía [...] están amuralladas; se abren puertas como si de un nuevo camino se tratara; pocas voces se oirán en contra de esta nueva intromisión que afectará más de lo que en un primer momento se podría imaginar. El ferrocarril [...] actuará como centro polarizador, como barrera, etc.» (Aguilar Civera, 1988, p. 145).

${ }^{31}$ Construir y organizar las estaciones (zonas de maniobras de las locomotoras, playas de vías para la clasificación y montaje de trenes, cocheras, talleres, andenes, almacenes, tinglados, zonas de embarque y almacenaje, servicios a viajeros, etcétera) sólo fue posible en las afueras de las ciudades, en donde existían grandes cantidades de suelo a precios asequibles.
}

tieron en la principal puerta de acceso a la ciudad y en polos de atracción del crecimiento urbano ${ }^{32}$. Una vez inauguradas, muchas ciudades concibieron planes para trazar calles que las unieran al casco urbano, las cuales no tardaron en acoger locales comerciales modernos y edificios representativos de la nueva clase social emergente ${ }^{33}$.

Valladolid fue, a este respecto, un paradigma. En 1850 , antes incluso de que se construyese la estación, ya se planteó la alineación y el ensanchamiento de algunas calles que facilitaran el acceso a la misma desde el centro urbano. A esa intención respondían, por ejemplo, los nuevos trazados de las calles Duque de la Victoria y Mendizábal, o la propuesta de un vial entre el Campillo y la estación de Martín Saracíbar, al que ya hemos hecho referencia. Ahora bien, el trazado definitivo de la calle que uniría la estación con el centro urbano se debe al arquitecto Ruiz Sierra, quien en 1880 presentó el Proyecto de alineaciones, edificación y apertura de nuevas calles

${ }^{32}$ En consonancia con el papel que desempeñaban las estaciones en el entramado urbano, al tiempo que para exaltar su identidad, la Compañía del Norte inauguró en 1890 el edificio actual de su estación, de dimensiones mucho mayores que el original (Terán, 1999, p. 93)

${ }_{33}$ Oviedo, León, Vitoria o Vigo son otras ciudades en las que la incorporación del ferrocarril a la trama urbana fue determinante en la articulación de su espacio burgués (Fernández Cuesta, Fernández Salinas y Quirós Linares, 2010, pp. 16-17). 


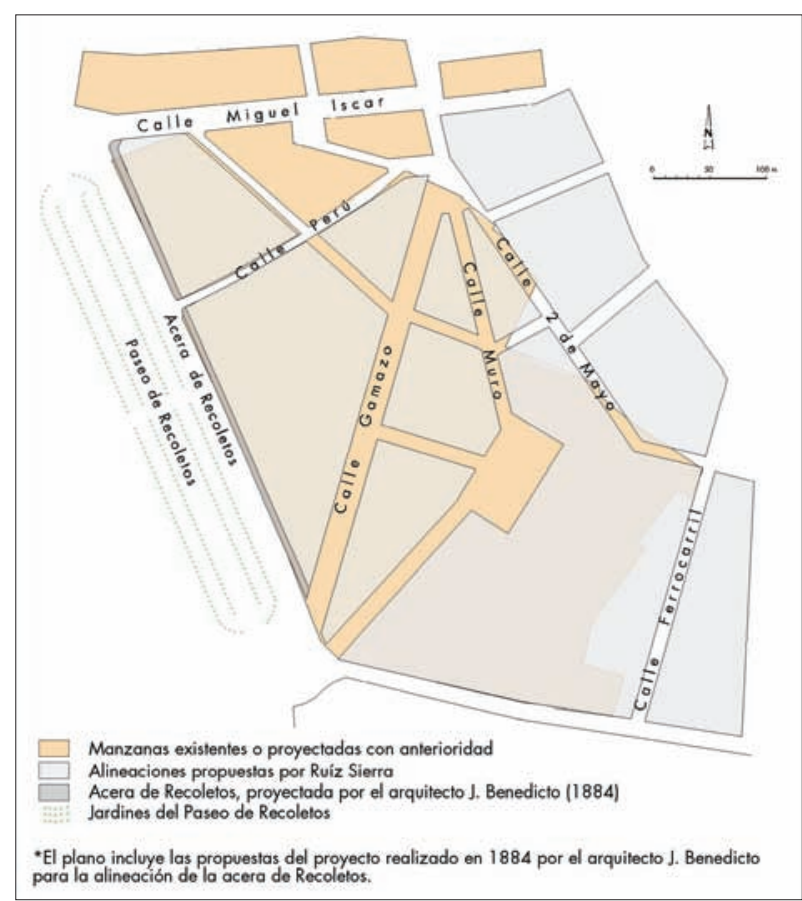

FIG. 30. Proyecto de alineaciones, edificación y apertura de nuevas calles entre el Campo Grande, el Rastro, la calle Panaderos y la estación. Arquitecto Ruiz Sierra, 1880. El plano incluye las propuestas del proyecto realizado en 1884 por el arquitecto J. Benedicto para la alineación de la acera de Recoletos. Fuente: elaboración propia a partir de los planos que aparecen en Álvarez Mora (2005).

entre el Campo Grande, el Rastro, la calle Panaderos y la estación (Álvarez Mora, 2005, p. 118). El plan diseñaba el trazado de la calle $\mathrm{Gamazo}^{34}$, que debía formar, junto con la del Duque de la Victoria, una gran vía de comunicación directa entre la plaza Mayor y la estación de Campo Grande. Pero incluía también el trazado de las calles Dos de Mayo (antes Joaquín Costa), Muro y Ferrocarril, que, junto con la de Gamazo y las alineaciones surgidas del Proyecto de alineación y edificación de la acera de Recoletos, del arquitecto J. Benedicto (1884), dio origen al falso ensanche de Gamazo, llamado así por su semejanza morfológico y funcional con esa figura urbanística aunque no es realmente un ensanche, pues nunca existió un proyecto que así se llamara, amparado por alguna de las leyes homónimas.

El proyecto de J. Benedicto, antes aludido, además de marcar la alineación de la Acera, Recoletos, introdu-

${ }^{34}$ Las obras de apertura de la calle Gamazo se iniciaron en 1890 y en 1893 habían concluido. El año siguiente (1894) se había terminado la calle Muro y antes de que acabara el siglo se encontraban en uso las de Mantilla, Colmenares y Ferrocarril (Virgili Blanquet, 1979, p. 68; Agapito y Revilla, 1937, pp. 79-80 y 259).

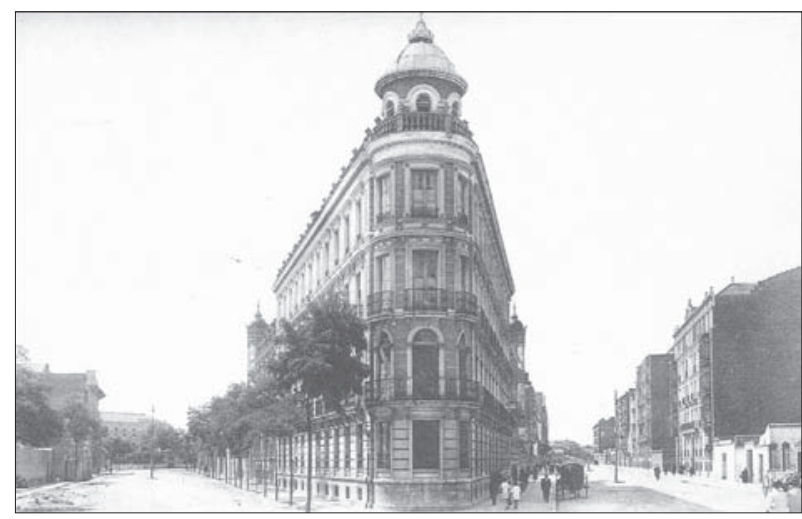

FIG. 31. La calle Gamazo forma junto con la del Duque de la Victoria una vía de comunicación directa entre la plaza Mayor y la estación de Campo Grande. Constituye, además, la arteria principal del falso ensanche al que ella misma da nombre. En su intersección con la calle Muro se construyó el edificio que aparece en la foto, hoy tristemente desaparecido, que nos evoca al famoso Flatiron Building de Nueva York.

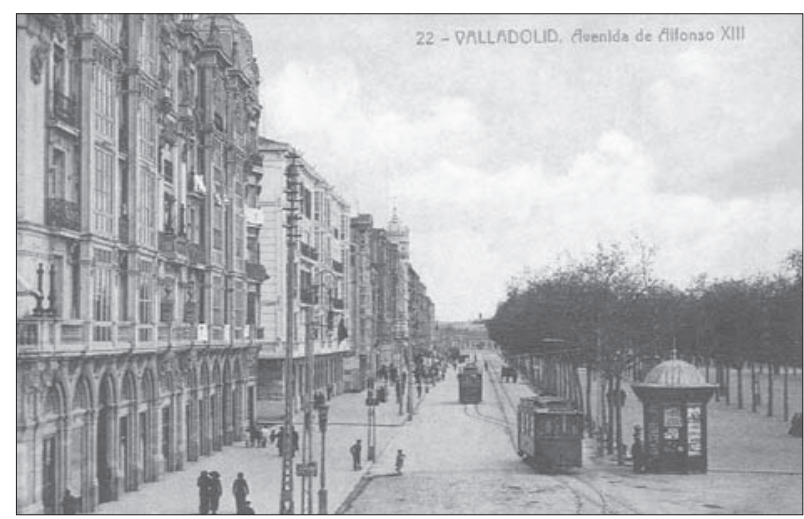

FIG. 32. La acera de Recoletos, frente occidental del falso ensanche de Gamazo, con sus edificios de elevada calidad estética y constructiva, perfectamente alineados, fue abierta a partir de 1884 y pronto se convirtió en lugar de residencia predilecto de la burguesía.

cía normas acerca de la morfología que habrían de tener los edificios que se levantaran sobre ella, y también diseñaba los jardines que la separarían del Campo Grande. Con todos estos elementos se buscaba lograr una elevada calidad estética y una imagen exterior unitaria (Álvarez Mora, 2005, pp. 118-119) que convirtiera a la acera de Recoletos en una de las arterias más codiciadas y emblemáticas del nuevo espacio residencial burgués.

\section{C) Las últimas obras de reforma interior ejecutadas durante las primeras décadas del siglo $\mathrm{XX}$}

Las obras de reforma interior descritas con anterioridad, realizadas para levantar en el corazón de la ciudad 


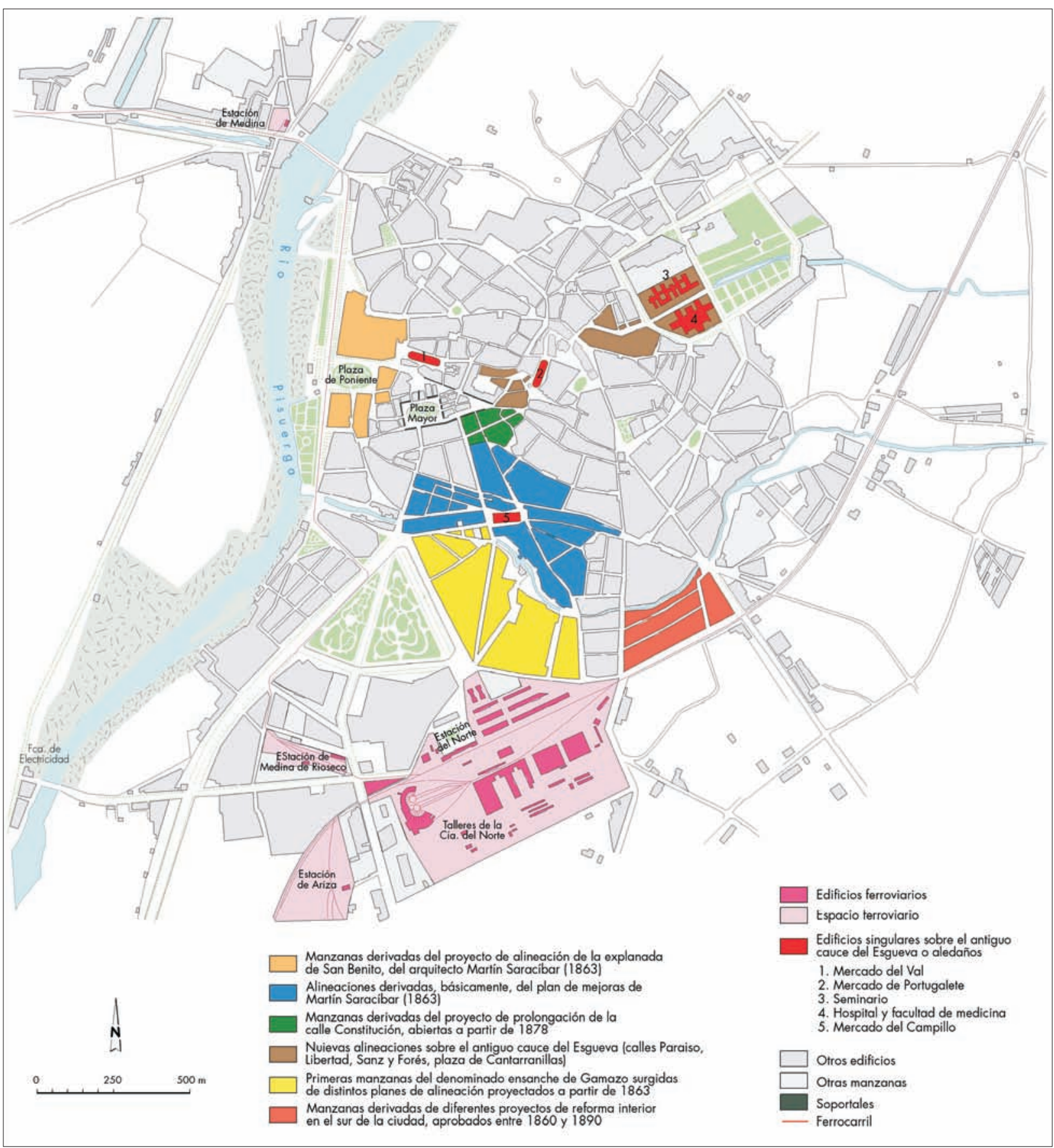

Fig. 33. Valladolid en 1896. Principales transformaciones urbanas desde 1863. Fuente: elaboración propia a partir del plano de Valladolid de la editorial Montaner y Simón (1896).

histórica un espacio adaptado a la burguesía, habían conseguido cambiar radicalmente la trama urbana entre la plaza de San Miguel y la estación de Campo Grande, de manera que en 1900 su fisonomía era muy distinta a la que tenía cincuenta años antes. Prácticamente, las Esguevas no eran más que un recuerdo del pasado y sobre sus cauces se erigían nuevas plazas, calles y equipamientos; las vías públicas eran más anchas y rectilíneas; era posi- 


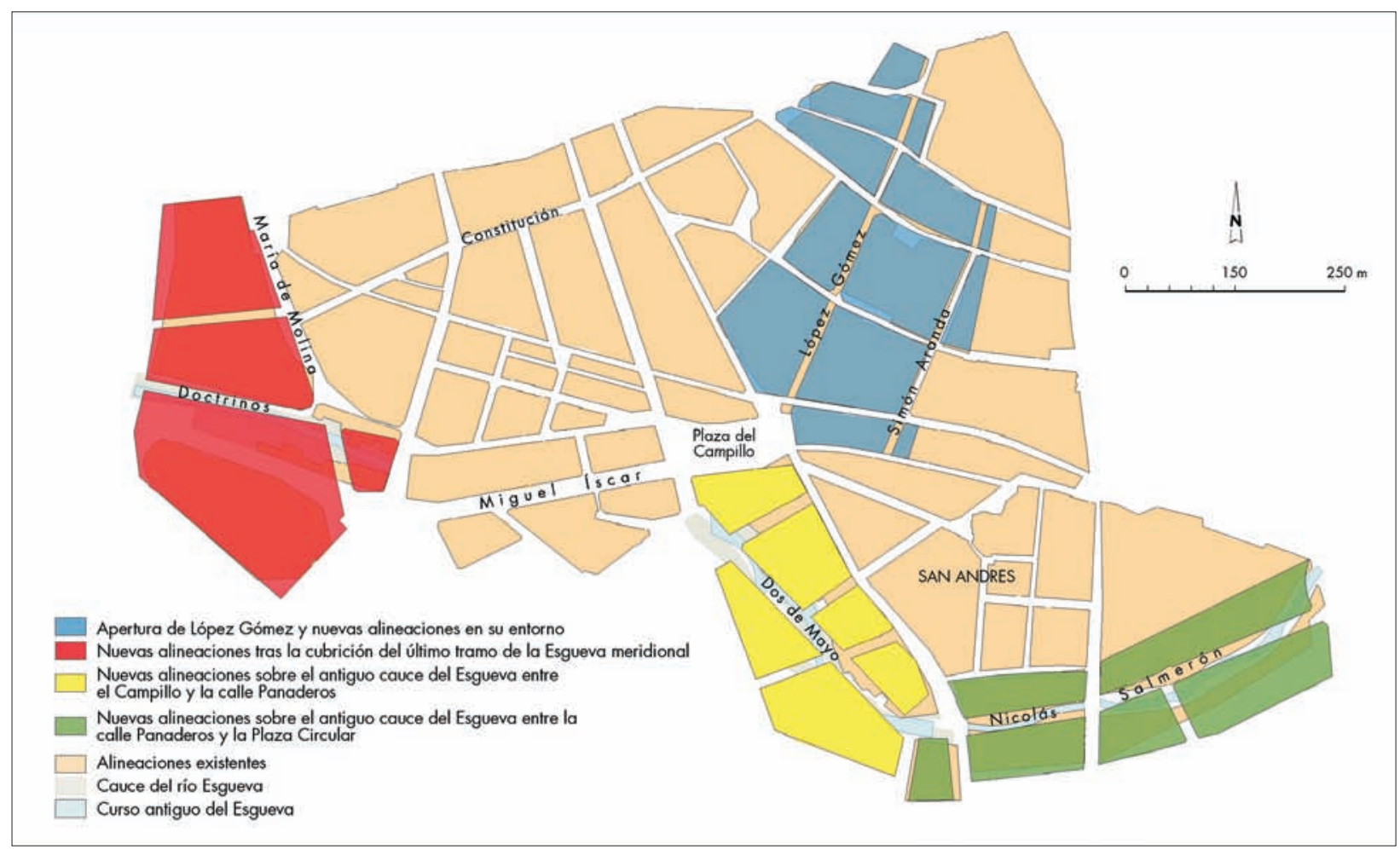

Fig. 34. Reforma interior en los entornos de López Gómez y el curso de la Esgueva meridional. Fuente: elaboración propia a partir de los planos de Valladolid, de los años 1850 y 1950, que aparecen en Carazo Lefort (2010).

ble desplazarse directamente desde la plaza Mayor a la estación; y el ferrocarril, con sus tres estaciones, era un elemento fundamental de la ciudad.

Ahora bien, entrado el siglo xx todavía no se había logrado la ansiada uniformidad estética y funcional de todo el conjunto que debería comportarse como espacio residencial predilecto de la burguesía y, al mismo tiempo, como centro comercial y de negocios de la ciudad. La forma definitiva de este espacio se alcanzó en la década de 1930, poco antes de que comenzara la guerra civil, y para ello fue necesario que municipalidad y propietarios del suelo siguieran promoviendo obras de apertura y rectificación de calles.

Entre esas obras destacaron las que confirieron su aspecto actual a la calle Santiago (Virgili Blanquet, 1979, pp. 61-62), ya entonces configurada como centro privilegiado del comercio minorista de la ciudad y lugar predilecto de paseo de la burguesía. Pero mayor incidencia sobre la fisonomía urbana tuvieron las obras de soterramiento del Esgueva donde todavía permanecía abierto. Del proyecto para cubrir el tramo que discurría entre Miguel Íscar y su desembocadura nacieron las calles Doctrinos y Veinte de Febrero, además de la alineación definitiva de María de Molina. Y sobre la bóveda construida para cubrir el cauce entre las plazas del Campillo y la Circular se abrieron, en 1919, la calle Dos de Mayo (Agapito y Revilla., 1937, pp. 142-143) y, en 1920, la de Nicolás Salmerón. Con la primera se concluyó la trama del falso ensanche de Gamazo; con la segunda se articuló el engarce entre la vieja trama del barrio de San Andrés y la que surgió de su ampliación hasta las vías del tren.

Pero más importantes aún que estas obras, si consideramos su significado urbanístico, fueron las que concluyeron con la apertura de la calle López Gómez, tal vez el mejor ejemplo vallisoletano de la idea de gran vía. La nueva arteria fue proyectada por el arquitecto J. Benedicto en 1882 para facilitar la comunicación directa entre la plaza del Campillo y la de la Universidad, y se trataba de una obra compleja, pues el trazado afectaba a cinco manzanas de la trama histórica y tres de ellas debían ser diseccionadas en dos, por eso no fue fácil su ejecución. Aunque las tareas de expropiación comenzaron poco después de aprobado el proyecto, sólo se dieron por finalizadas en 1896 (Virgili Blanquet, 1979, pp. 68-69; Agapito y Revilla, 1937, pp. 250-251; Álvarez Mora, 2005, pp. 129-131). Las de apertura propiamente dicha se iniciaron 


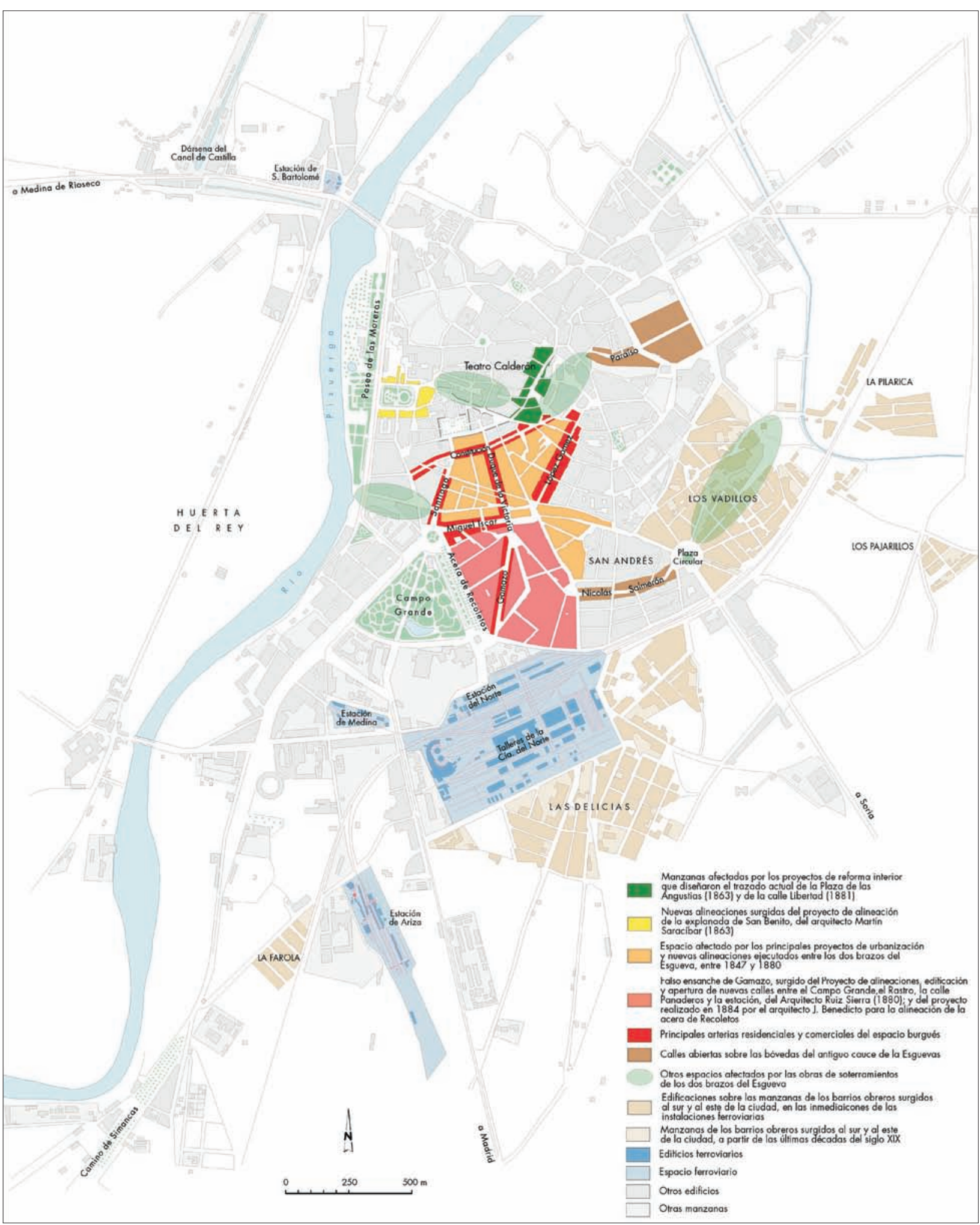

FIG. 35. Valladolid 1934. Síntesis de la ciudad burguesa. Fuente: elaboración propia a partir del plano de Valladolid del Cuerpo de Estado Mayor del Ejército (1934) y del plano de Valladolid realizado por la Oficina Técnica del Ayuntamiento (1935). 
ese mismo año y en 1911 ya se encontraban concluidas, al menos así se desprende del plano de Valladolid que aparece en la España Regional (La España Regional, 1915, aprox.).

El espacio burgués quedó definitivamente configurado con las nuevas alineaciones que se le dieron a otras calles del entorno de López Gómez, como Fray Luis de León, Núñez de Arce y, sobre todo, Simón Aranda, cuyo nuevo trazado requirió de la ruptura de dos manzanas antiguas.

\section{CONCLUSIONES}

Como en otras ciudades españolas, en Valladolid la fase culminante de la etapa de formación de la ciudad burguesa se prolongó desde 1850 hasta los inicios de la guerra civil. Pero ahí terminan las similitudes. La existencia de grandes baldíos en el interior de su antiguo recinto intramuros explica la ausencia de la figura del ensanche para organizar un espacio burgués que diera satisfacción a las necesidades residenciales, de ocio, de representación y de negocio de la nueva clase social. Este espacio se construyó sobre la trama histórica heredada del Antiguo Régimen, mediante el uso preferente de la legislación aprobada para ejecutar obras de reforma interior, y se actuó con tal intensidad que se transformó de manera radical el legado recibido, con la consecuente pérdida de la identidad histórica del conjunto, muchas veces irreconocible. En amplias zonas del casco histórico la trama irregular, los palacios, los conventos y otros edificios de interés, fueron derribados y sustituidos por amplias avenidas perfectamente alineadas, jalonadas de edificios desarrollados en altura, de estética semejante a los que podemos encontrar en los ensanches de otras ciudades. Avenidas y edificios que nos transmiten un paisaje urbano que en absoluto se corresponde ni con la antigüedad ni con la historia urbana de los solares que ocupan, complicando así su comprensión y su interpretación. Y no es de extrañar, dado que no es fácil imaginar que la Plaza de San Miguel, rodeada de edificios impersonales de seis o más plantas construidos con materiales intemporales, sea en realidad el lugar en el que nació la ciudad.

\section{FUENTES CARTOGRÁFICAS Y BIBLIOGRAFÍA}

\section{Planos de Valladolid}

Bentura, S. (1738): Plano de la ciudad de Valladolid en 1738. Copia de J. Agapito Revilla.
Marrón, F. (1839): Plano de la ciudad de Valladolid con las obras de defensa ejecutadas en los años 1836 y 1837.

Coello, F. (1852): Plano de Valladolid.

Pérez de las Rozas, J. (1863): Plano de la ciudad de Valladolid construido por disposición y a costa del ilustre Ayuntamiento.

Montero, J. (1896): Plano de Valladolid.

Martín, A. (1911): Nuevo plano de Valladolid publicado y revisado por el Ayuntamiento.

Instituto Geográfico y Estadístico (1915): Término municipal de Valladolid. Hojas 63 a 107.

Cuerpo de Estado Mayor (1934): Cartografía militar de España. Plano director Valladolid. Hoja 327-IV.

\section{BibLIOGRAFÍA}

Agapito y Revilla, J. (1937): Las calles de Valladolid. Casa Martín, Valladolid.

Aguilar Civera, I., (1988): La estación de ferrocarril, puerta de la ciudad. Generalitat Valenciana, Valencia.

Almuiña FernándeZ, C. (1985): «De la vieja sociedad estamental al triunfo de la burguesía harinera», en Valladolid en el siglo XIX. Ateneo de Valladolid, Valladolid.

Alonso Baquer, M. (1985): «Los fundamentos de la división territorial militar de España», en H. Capel y J. Clusa (coords.): La organización territorial de empresas e instituciones públicas en España. Universitat de Barcelona, Barcelona, pp. 77-102.

Altés Bustelo, J. (1998): Plaza Mayor de Valladolid: el proyecto de Francisco de Salamanca para la reedificación del centro de Valladolid en 1561. Ayuntamiento de Valladolid.

Álvarez Mora, A. (1994): «Valladolid», en M. Guardia, F. J. Monclús y J. L. Oyón (dirs.): Atlas histórico de ciudades europeas. Península Ibérica. Salvat, Barcelona, pp. 267-290.

- (2005): La construcción histórica de Valladolid. Proyecto de ciudad y lógica de clases. Universidad de Valladolid, Valladolid.

Bassols Coma, M. (1973): Génesis y evolución del derecho urbanístico español (1812-1956). Montecorvo, Madrid.

Begines Ramírez, Z. (1973): Los Pajarillos Altos de Valladolid. Valladolid.

Bennassar, B. (1967): Valladolid au Siècle d'Or. Une ville de Castille et sa campagne au XVİ̀ siècle. París.

— (1981): «Valladolid en el reinado de Felipe II», en Valladolid, corazón del mundo hispánico. Siglo XVI. Ateneo de Valladolid, Valladolid, pp. 71-136. 
Bonet Correa, A. (1978): «Plaza Mayor», en M. Terán Álvarez, M. Molina Campuzano, J. M. Azcárate Ristori, P. Navascués Palacio y A. Bonet Correa (1978): Madrid. Espasa-Calpe, Madrid, pp. 41-60.

Burgueño, J. (1996): Geografía política de la España constitucional. La división provincial. Centro de Estudios Constitucionales, Madrid.

Cabo, A., y E. Manero (1988): Geografía de Castilla y León. Ámbito, Valladolid, pp. 121-166.

Calderón Calderón, B. (1991): Cartografía y ciudad: Valladolid en el siglo XIX. Transformaciones espaciales en el inicio del proceso urbano contemporáneo. Grapheus, Valladolid.

- (2007): «La plaza mayor de Valladolid: 1561-2005. Un lugar-escenario de permanente referencia en la estructura urbana», en E. García Zarza (coord.): La plaza mayor de Salamanca: importancia urbana y relación con plazas mayores españolas e hispanoamericanas. Universidad de Salamanca, Salamanca.

- S. Mata y J. L. SÁinz (1982): «La cartografía de Valladolid. 1- La ciudad de Valladolid desde sus orígenes hasta la llegada del ferrocarril», bajo la dirección de S. Marchán Fiz y L. Moya González. Ayuntamiento de Valladolid, Valladolid.

- S. Mata y J. L. SÁinz (1985): «La cartografía de Valladolid. 2- Valladolid, 1863-1931», bajo la dirección de S. Marchán Fiz y L. Moya González. Ayuntamiento de Valladolid, Valladolid.

- J. L. SÁinz Guerra y S. MAta (1991): Cartografía histórica de la ciudad de Valladolid. Ayuntamiento de Valladolid, Valladolid.

CAMERon, R. (1992): Historia económica mundial. Desde el Paleolítico hasta el presente. Alianza, Madrid.

CAPEL, H. (1975): Capitalismo y morfología urbana en España. Los Libros de la Frontera, Barcelona.

- y J. Clusa (coords.) (1985): La organización territorial de empresas e instituciones públicas en España. Universitat de Barcelona, Barcelona.

CArazo Lefort, E. (2010): Valladolid, forma urbis. Restitución infográfica del patrimonio urbano perdido. Universidad de Valladolid, Valladolid.

Cervera Vera, L. (1978): «La época de los Austrias», en A. García y Bellido, L. Torres Balba, L. Cervera, F. Chueca y P. Bidagor (1987): Resumen histórico del urbanismo en España. IEAL, Madrid, pp. 172209.

Coello, F.: Atlas de España y sus posesiones de ultramar. 1847-1870.

Comín Comín, F., P. Martín Aceña, M. Muñoz Rubio y J. Vidal Olivares (1998): 150 años de historia de los ferrocarriles españoles. 2 vols., Fundación de los Ferrocarriles Españoles. Madrid.

Coronas González, S. (1998): Estudio de historia de derecho público. Tirant lo Blanch, Valencia.

Delgado Viñas, C. (1993): Las pequeñas y medianas capitales de provincia en el proceso de modernización del sistema urbano español. Universidad de Las Palmas, Las Palmas.

DíAZ VALCÁRCEL, L. (1985): «La organización territorial del poder judicial», en H. Capel y J. Clusa (coords.): La organización territorial de empresas e instituciones públicas en España. Universitat de Barcelona, Barcelona, pp. 10-75.

Díez EspinosA, J. R. (1985): «Agricultura, industria y comercio», en Valladolid en el siglo XIX. Ateneo de Valladolid, Valladolid, pp. 317-350.

Diputación de Valladolid (2002): Palacio Real. Diputación Provincial de Valladolid, Salamanca.

Fernández Cuesta, G. (2011): «Crecimiento urbano y modernización en España entre 1857 y 1900». Ería. Revista Cuatrimestral de Geografía (Oviedo), núm. 84-85, pp. 5-46.

- (2012): «San Sebastián: un modelo de construcción de la ciudad burguesa en España». Ería. Revista Cuatrimestral de Geografía (Oviedo), núm. 88, pp. 101-128.

- V. Fernández Salinas y F. Quirós Linares (2010): «Los espacios urbanos», en G. Fernández Cuesta y F. Quirós Linares (2010): Atlas temático de España. Vol. 1, Nobel, Oviedo, pp. 9-30.

- y F. Quirós LinARes (2010): Atlas temático de España. 4 vols., Nobel, Oviedo.

FernÁndeZ DE Diego, E. (1971): El barrio de San Andrés en la ciudad de Valladolid. Departamento de Geografía de la Universidad de Valladolid, Valladolid.

Fernández del Hoyo, M. ${ }^{a}$ A. (1981): Desarrollo urbano y proceso histórico del Campo Grande de Valladolid. Ayuntamiento de Valladolid, Valladolid.

García Bellido, A., L. Torres Balbás, L. Cervera, F. Chueca y P. Bidagor (1987): Resumen histórico del urbanismo en España. Instituto del Estudios de la Administración Local, Madrid.

García Fernández, J. (1974): Crecimiento y estructura urbana de Valladolid. Los Libros de la Frontera, Barcelona.

- (2000): Valladolid, de la ciudad a la aglomeración. Ariel, Barcelona.

García ZARZA, E. (coord.): La plaza mayor de Salamanca: importancia urbana y relación con plazas mayores españolas e hispanoamericanas. Universidad de Salamanca, Salamanca. 
Guàrdia, M., F. J. Monclús y J. L. Oyón (1994): Atlas histórico de las ciudades europeas. La península ibérica. Salvat, Barcelona.

Gutiérrez Alonso, A. (1989): Estudio sobre la decadencia de Castilla. La ciudad de Valladolid en el siglo XVII. Universidad de Valladolid, Valladolid.

GutiérRez Baños, F. (1999): «Los palacios de la Magdalena. Contribución al estudio de las residencias reales de Valladolid». En Valladolid, historia de una ciudad. Congreso internacional. 3 vols., Ayuntamiento de Valladolid, Valladolid, pp. 71-73.

IbÁÑEz Palomares, J. M. a (1981): Valladolid, 1900-1931. Ateneo de Valladolid, Valladolid.

IgLeSIAS Rouco, L. S. (1978): Urbanismo y arquitectura de Valladolid. Primera mitad del siglo XIX. Ayuntamiento de Valladolid, Valladolid.

JiMÉNEZ GARCÍA, M (1992): La evolución urbana de Valladolid en relación con el ferrocarril. Ámbito, Valladolid.

La España Regional. 4 vols., Martín Editor, Barcelona, sin fecha (aprox. 1915).

Manero Miguel, F. (1983): La industria en Castilla y León. Dinámica, caracteres e impacto. Ámbito, Valladolid.

- (1988a): «Caracteres y condicionamientos del proceso de industrialización», en A. Cabo y F. Manero: Geografía de Castilla y León. Vol. v: Industria y recursos minero-energéticos. Ámbito, Valladolid, pp. 9-36.

- (1988b): «La estructuras industriales», en A. Cabo y F. Manero: Geografía de Castilla y León. Vol. v: Industria y recursos minero-energéticos. Ámbito, Valladolid, pp. 121-166.

Manual histórico y descriptivo de Valladolid. Hijos de Rodríguez Editores, Valladolid, 1861.

Marchán Fiz, S., y L. Moya González (dirs.) (1982): La cartografía de Valladolid, parte primera. Ayuntamiento de Valladolid, Valladolid.

Martín GonzÁlez, J. J. (1981): «Urbanismo y arquitectura de Valladolid durante el Renacimiento». En Valladolid, corazón del mundo hispánico. Siglo XVI. Ateneo de Valladolid, Valladolid, pp. 137-178.

Mata PÉREz, S. (ed.): Arquitecturas en Valladolid. Tradición y modernidad, 1900-1950. Colegio de Arquitectos de Valladolid, Valladolid.

MOPU (1983): Ingeniería en la época romántica. Las obras públicas en España alrededor de 1860. MOPU, Madrid.

Moreno LÁzaro, J. (2003): «Historia de una quimera. La industria algodonera en Castilla La Vieja, 1846-
1913». Revista de Historia industrial, núm. 23, pp. 173-196.

Palomares IbÁÑEz, J. M. (dir.) (1989): Historia de la Universidad de Valladolid. Universidad de Valladolid, Salamanca.

Pirenne, H. (1974): Historia económica y social de la Edad Media. FCE, México.

Quirós LinARES, F. (1991): Las ciudades Españolas en el siglo XIX. Ámbito, Valladolid.

Ribot García, L. A. (1981): «Valladolid durante el reinado de Carlos I», en Valladolid, corazón del mundo hispánico. Siglo XVI. Ateneo de Valladolid, Valladolid, pp. 11-70.

Rivera Blanco, J., y J. Pérez Gil (2002): «El Palacio Real de Valladolid», en Diputación de Valladolid: Plan director del Palacio Real de Valladolid. Diputación de Valladolid. Valladolid, pp. 13-66.

RodríGuEz MARTínEz, L. (1981): «Valladolid, capital benedictina de España en el siglo XVI», en Valladolid, corazón del mundo hispánico. Siglo XVI. Ateneo de Valladolid, Valladolid, pp. 277-301.

Rucquor, Adeline (1982): Valladolid en la Edad Media: la villa del Esgueva. Ayuntamiento de Valladolid, Valladolid.

Rueda Hernanz, G., y P. Carasa Soto (1983): Estructura socio-profesional y socio-económica de Valladolid en 1840-41 como prototipo de una ciudad de Castilla la Vieja. Consejo Superior de Investigaciones Científicas, Madrid.

SÁez Hidalgo, I. (1994): El canal de Castilla. Junta de Castilla y León, Salamanca.

SÁnchez Movellán, E. (1989): «Época medieval», en Historia de la Universidad de Valladolid. Universidad de Valladolid, Salamanca.

Terán, F. (1999): Historia del urbanismo en España, siglos XIX y XX. Cátedra, Madrid.

Terán Álvarez, M., M. Molina Campuzano, J. M. AzCÁrate Ristori, P. Navascués Palacio y A. Bonet CoRREA (1978): Madrid. Espasa-Calpe, Madrid.

Torres B Albás, L. (1987): «La Edad Media», en A. García y Bellido, L. Torres Balbás, L. Cervera, F. Chueca y P. Bigador: Resumen histórico del urbanismo en España. IEAL, Madrid, pp. 68-172.

Tortella, G. (1994): El desarrollo de la España contemporánea. Historia económica de los siglos XIX y XX. Alianza, Madrid.

UrReA, Jesús (1996): Arquitectura y nobleza. Casas y palacios de Valladolid. Junta de Castilla y León, Valladolid.

VALDEÓN BARUQUE, J. (1989): «La universidad medieval: 
introducción», en J. M. Palomares Ibáñez: Historia de la Universidad de Valladolid. Universidad de Valladolid, Salamanca.

- (1999): «Valladolid villa», en Valladolid, historia de una ciudad. Ayuntamiento de Valladolid, Valladolid, pp. 179-191.

Valladolid, corazón del mundo hispánico. Siglo XVI. Ateneo de Valladolid, Valladolid, 1981.

Valladolid en el siglo XIX. Ateneo de Valladolid, Valladolid, 1985.
Valladolid, historia de una ciudad. Congreso internacional. 3 vols., Ayuntamiento de Valladolid, Valladolid, 1999.

Virgili Blanquet, M. a A. (1979): Desarrollo urbanístico y arquitectónico de Valladolid (1851-1936). Ayuntamiento de Valladolid, Valladolid.

- (1985): «Urbanismo y arquitectura», en Valladolid en el siglo XIX. Ateneo de Valladolid, Valladolid, pp. 458-504.

WAIs, F. (1974): Historia de los ferrocarriles españoles. Editora Nacional, Madrid. 